\title{
INTERNAL WAVES IN THE SEA
}
A summary of published information with notes on applications to naval operations

O. S. Lee - Research and Development Report - 26 July 1965 U. S. NAVY ELECTRONICS LABORATORY, SAN DIEGO, CALIFORNIA 92152 - A BUREAU OF SHIPS LABORATORY 


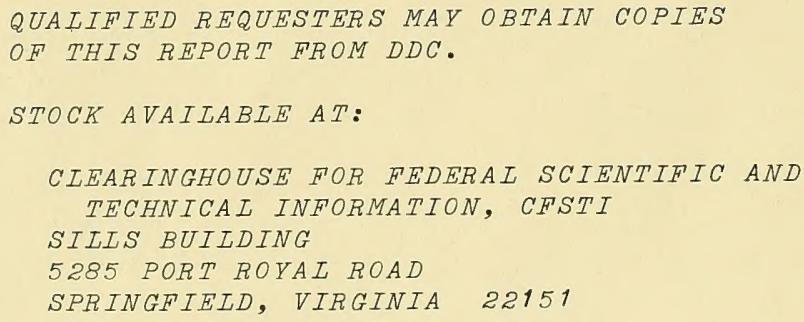




\section{THE PROBLEM}

Investigate oceanographic factors, particularly internal waves, that influence naval operations and equipment. This report presents a bibliography of over 300 listings and summarizes important published results of investigation.

\section{RESULTS}

1. Internal waves exist in the ocean as a rule rather than an exception. Energy is transported by them in channels that are similar to sound channels. Their effect on naval exercises and equipment, particularly functions involving the use of underwater sound, can be expected to be more pronounced in these channels.

2. Although theory and observation are still not adequate for a full understanding of the phenomenon, western literature prior to June 1963 contains more than 300 publications dealing with internal waves in the atmosphere, lakes, and seas.

3. These publications are listed in the comprehensive bibliography which is part of this report.

\section{RECOMMENDATIONS}

1. Locate, compile, and keep up to date available information concerning internal waves in the sea; use both western and eastern sources.

2. Exploit this information in naval research. 


\section{ADMINISTRATIVE INFORMATION}

This work was done in the Marine Environment Division under SR 00403 01, Task 0580 (NEL L40451) from June 1963 to June 1964. The report was approved for publication 26 July 1965. The bibliography could not have been compiled without the help of the NEL library staff and D. Quist. Comments on the manuscript by G. H. Curl and E. C. LaFond are gratefully acknowledged.

\section{CONTENTS}

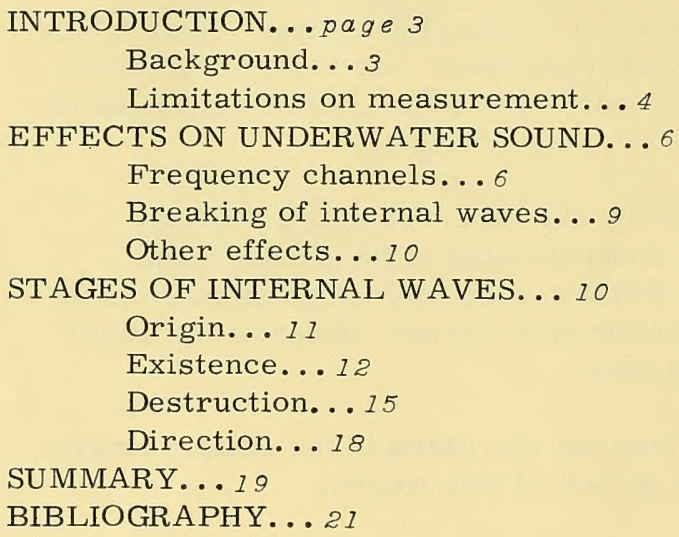

\section{ILLUSTRATIONS}

1 Distribution of papers on internal waves by year...page 4

2 An example of the mode structure of internal waves... 13

3 Observations of temperature at three stations...16,17 


\section{INTRODUCTION}

Internal waves affect the propagation of underwater sound and therefore also the U. S. Navy operational use of sonar through the phenomena of refraction and scattering. Refraction of the sound rays by internal waves can result in sonar bearing errors and in fluctuations of bearing determinations. Fluctuation in sound intensity occurs when multipath interference is present, particularly when one path passes through moving internal waves. The apparent sound attenuation may be aggravated by loss of energy from the beam by scattering from intervening internal waves. Some sound may be scattered back to the source by internal waves to increase the reverberation background of the sonar.

\section{Background}

Figure 1 shows the distribution of published papers on internal waves as a function of time. The graph shows only casual interest in internal waves after the first paper was written by G. G. Stokes in 1847. Attention increased around the year 1900, and peaks occurred circa 1910 and in the 1930 's. The decline in the number of published papers after 1938 was apparently due to WWII. The last year in which no paper was published was 1944 , and from then until now the number has steadily increased. Figure 1 includes papers through 1962, and the bibliography is comprehensive through June 1963.

Observational data on internal waves have been accumulating for the past 60 to 70 years. Most of these data were confined to the Scandinavian countries until about 1925. Until 1950, few of the observations on internal waves had statistical significance. Since that time, three unaliased spectra have been published to which statistical significance can be assigned. These data were observed in the Baltic Sea, off Bermuda, and off the California coast. All were taken from fixed points and consequently do not permit any study of geographical changes. Data taken from towed thermistor chains on the east and west coasts of the 


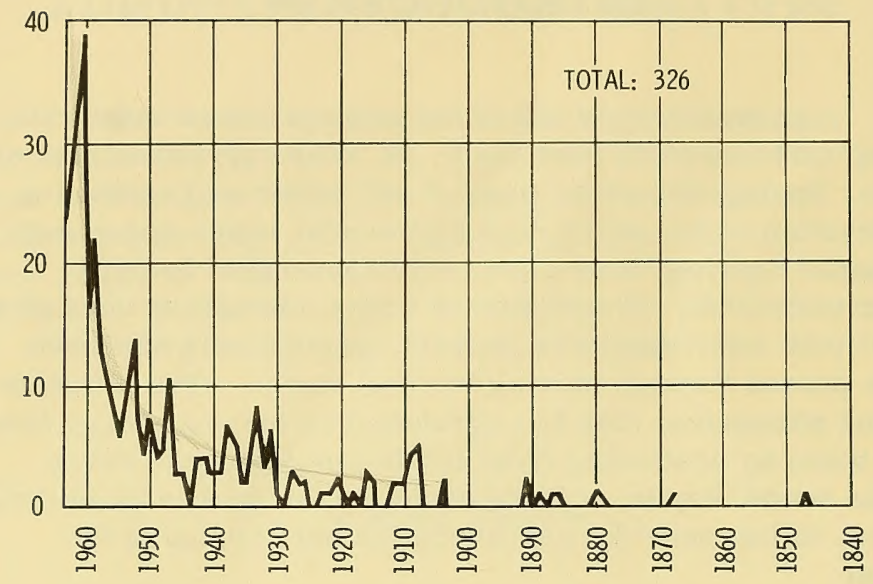

Figure 1. Distribution of papers on internal waves by year.

U. S. help this problem somewhat, but interpretation of the data is difficult. For example, towing of thermistors introduces a Doppler shift into any periodic phenomenon that is in motion, and the magnitude of the shift is unknown because the directionality of internal waves is also unknown.

A large number of temperature observations in the ocean have been made for purposes other than the study of internal waves. Some of the features of these observations have been explained on the basis of internal waves, for example, the variability in dynamic heights, from which dynamic currents are computed. Changes in the relative topography of the sea surface of \pm 1 centimeter have been estimated for the region off Southern California.

\section{Limitations on Measurement}

The ability to measure internal waves is presently confined to the ability to measure temperature in the ocean. It is not yet possible to measure density in situ continuously. Internal waves are measured by assuming 
that changes in temperature are conservative. Consequently, both salinity and density surfaces undergo the same variance over time and space.

The most widely used device for measuring temperature continuously in the ocean has been the thermistor. The thermocouple has been used with less success because it requires much more sensitive equipment for sensing and recording the output. The bathythermograph and the reversing thermometer have also been employed, but these instruments introduce aliasing. Other devices, such as platinum resistance thermometers and vibrotrons, have been utilized, but to a considerably less extent.

Current meters provide perhaps the most direct way to measure internal waves. They have had limited use, and there are a number of problems associated with the employment of them, such as motion of the device and vortex shedding, which introduce erroneous data into the records. It is desirable to overcome these problems because there are serious handicaps in measuring internal waves by the use of temperature devices.

There appears to be no lag in the development of electronic equipment capable of handling signals from these transducers and recording them. Once a method of measuring has been selected, there is no problem evident in obtaining the necessary electronic equipment to apply it, although integrating components and adapting the system for a particular use usually involve a period of several months.

Width of the spectrum and the structure of the modes must be given due regard in studies of internal waves. The latter requires that temperature measurements be made from surface to bottom. In deeper layers of the ocean, temperature gradients are weak -- as low as $0.0010^{\circ}$ per meter. Although many claims about accuracy and stability are made, it is probable that considerable equipment development is required in order to meet the sensitivity, accuracy, and stability requirements.

In addition, it is necessary for the equipment to record for long periods of time under the rigors of the marine environment (constant motion, solvency of sea water, and extreme pressure) and with the usual power limitation of a small, isolated system. 


\section{EFFECTS ON UNDER WATER SOUND}

The most direct applications of reports on internal waves are in connection with underwater sound. Numerical evaluation of the effects is known for only one case, wherein sound rays pass through a sharply defined internal wave at steep angles in shallow water. A wide knowledge of the amplitudes, wavelengths, direction of travel, and geographic and seasonal distributions of internal waves is required to evaluate the importance of these effects. Others, such as the release of gas bubbles (which scatter sound) by passage of a large-amplitude internal wave through saturated sea water, may be important.

Three fundamental factors affect the velocity of sound in sea water -- temperature, salinity, and pressure. Anything that introduces time changes or space changes in these properties will also bring in changes in the velocity of sound in the sea. The spectrum of time changes in the velocity of sound at a fixed point is directly proportional to the spectrum of time changes in any conservative property at that point. The latter spectrum can be determined from temperature measurements (provided heating at the boundaries is neglected), which are by far the easiest and most inexpensive that can be made in the ocean. In two cases an estimated 75 to 95 percent of the variance of a 3day temperature record in shallow water was caused by internal waves. This estimate accounts for variance at frequencies of free internal waves. The range covers periods from about 5 minutes to 24 hours at $30^{\circ} \mathrm{N}$.

\section{Frequency Channels}

Sound velocity in the ocean has a minimum at a depth of about 400 meters. The velocity minimum is the cause of the sound channel that has its axis at the level of the velocity minimum. Most of any omnidirectional sound released near the minimum is retained in the channel by refraction. This is a process by which direction of sound 
waves constantly tends toward a velocity minimum. Sound energy concentration in the sound channel is therefore engendered by a retaining process.

Another channel for horizontal energy transmission exists in the ocean. The identity of this channel involves transverse waves and their frequency maxima. These are internal waves the amplitude of which is a function of depth and the maximum frequency of which is the Väisälä frequency (also a function of depth).

The significance of the Väisälä, or stability, frequency (usually designated by $N$ ) can be illustrated by considering a small particle of fluid. A bit of fluid adiabatically displaced from its zero-order position and allowed to move freely, will oscillate at the Väisälä frequency provided entropy remains constant. The bit responds to a balance between buoyant and inertial forces. Pressure inside the bit becomes that of the fluid outside. When the magnitudes of density-change inside and outside the bit are equal, it remains in its displaced position. $N$ is zero in this case and stability is neutral. When density changes inside are larger in magnitude than those outside, the bit continues its displacement without oscillating, and the fluid is unstable. The fluid is stably stratified when density change outside is greater than that inside, and the particle will oscillate about its equilibrium position after initial displacement. Application of the stability frequency to internal wave motion is immediately apparent.

Internal perturbations do not progress as free waves at frequencies above the stability frequency. This phenomenon creates energy channels or frequency channels for internal waves that are as well defined as the sound channels in the ocean.

Higher-frequency internal waves are limited to regions near the maximum of $N$, but lower frequencies are not excluded. Frequencies lower than the minimum of $N *$

* Minimum of $N$ is used for convenience with the understanding that a channel can be defined as the region between $z_{1}$ and $z_{2}$ where $N\left(z_{1}\right)=N\left(z_{2}\right)$. 
may exist at all depths, but higher frequencies are excluded from depths having low stability frequency. A wider band of frequencies existing at depths of $N_{\max }$ sustains a frequency channel for internal waves by a selective process, as compared to a retaining process for the sound channel. Each frequency transports energy at its group velocity, and the frequency channel is therefore a channel for horizontal flux of energy, which is the same net effect of the sound channel.

Little is known about the relative importance of the various modes of internal waves in the ocean. On the other hand, the nature of the stability frequency is such that frequencies near the maximum of $N$ must have their largest displacements in the frequency channel. Waves of frequency lower than $N_{\text {min }}$ have no such requirement, and it is not known at what depths the various modes concentrate the horizontal flux of energy. An estimate can be based upon simple formulae. Starting with the energy equation for internal waves and the approximation

$$
\rho=\bar{\rho} e \frac{1}{\rho_{0}} \frac{d \rho_{0}}{d z} z,
$$

Kraus*(1964) arrived at an expression for total potential energy per unit area (horizontal) of the $n$th mode:

$$
E_{p o t}=\frac{1}{4} g \frac{1}{\rho_{0}} \frac{d \rho_{0}}{d z} a_{n}{ }^{2} H
$$

where $a_{n}$ is amplitude of the $n$th mode, $H$ is total depth, $\theta$ is the acceleration due to gravity, $\rho_{\circ}$ is the zero-order density of seawater, and $E_{p o t}$ is total potential energy per unit horizontal area. Energy per unit volume is estimated from

$$
\frac{E_{p o t}}{H}=\frac{1}{4} g \frac{1}{\rho_{0}} \frac{d \rho_{0}}{d z} a_{n}{ }^{2}
$$

*Book in process 
Hydrographic data (at $39^{\circ} 20^{\prime} \mathrm{N}, 50^{\circ} 50^{\prime} \mathrm{W}$ ) taken from figure 7 of Fjeldstad (1933) give the following values:

$$
\frac{1}{\rho_{0}} \frac{d \rho_{0}}{d z} \cong 2 \times 10^{-5}
$$

below the permanent thermocline at 1300 meters and

$$
\frac{1}{\rho_{0}} \frac{d \rho_{0}}{d z} \cong 6 \times 10^{-4}
$$

in a rather weak permanent thermocline at 700 meters. Using these values in the equation and taking the ratio of specific energies, we have

$$
30 \frac{\left(a_{7}\right)^{2} n}{\left(a_{13}\right)_{n}^{2}},
$$

approximately, where $a_{7 n}$ and $a_{13 n}$ are the amplitudes of the $n$th modes at 700 and 1300 meters respectively. Thus, if displacements inside the permanent thermocline are smaller by an order of magnitude than those outside, the energies are still about the same. Evidently more energy is transmitted horizontally in the frequency channel because a wider band of frequencies is progressing there.

\section{Breaking of Internal Waves}

Internal waves travel horizontally, and some of them must finally contact bottom near shore. That they reflect, is a mathematical possibility, but not yet a matter of observation. Directions found by observation in very shallow water do not indicate any reflection from shore. All the energy transmitted by internal waves can end as heat, but if it is assumed for the moment that some goes into potential energy, density surfaces would be driven 
upward as internal waves are destroyed near shore until other processes set in to maintain dynamic equilibrium.

Scalar surfaces tend to parallel the bottom near shore, and uplifted density surfaces near shore can be observed in cross-sectional plots of density such as those found in various atlases of oceanographic data. Horizontal gradients, in addition to vertical gradients, would be expected to be more important in coastal waters than in the deep, open sea. The importance of these horizontal gradients has not been investigated, and they are ignored in acoustic models assumed for the ocean.

\section{Other Effects}

In addition to fluctuation in sound speed and thus sound refraction, numerous other changes in the sea caused by internal waves are applicable to naval operations. These include buoyancy changes, water motions, water mixing, and displacement of water properties. Mathematical analyses have been conducted on the generation of internal waves by idealized bodies moving in stratified water. This has its obvious application to submarine detection, provided small signals can be discerned from a high background of natural internal waves.

\section{STAGES OF INTERNAL WAVES}

The studies of internal waves listed in the bibliography can be placed under three general subject headings -origin, existence, and destruction. Most of the reports have treated one of these phases without regard for the other two. 


\section{Origin}

Some theory regarding the origin of internal waves exists. One school of thought believes that internal tides originate directly from tidal forces. According to this idea, the internal waves begin at a frequency equal to the tidal frequency but at wavelengths of free waves. Another opinion contends that internal waves originate when currents pass over bottom irregularities. Origin by this process would be particularly noticeable in the region of the shelf break. Model experiments with two-layer systems indicate that internal waves start where such changes of bottom topography occur. Modeling systems without jump layers, that is, with arbitrary but stable density distribution, have evidently not been attempted.

Mathematical analysis of shear currents in the ocean leads to still another possible origin for internal waves. The analysis indicates that under certain idealized conditions, a nonbalanced velocity field in the process of adjusting toward geostrophic flow can lose energy to oscillating modes.

Although some recent progress has been made, almost nothing is known of nonlinear interactions. For example, shear currents might produce internal waves. Conversely, the question arises as to whether shear will reduce the coherence of waves as they travel through shear layers and feed energy back into the nonperiodic motion.

Some recent developments indicate that steady or low-frequency surface tides flowing over a rough bottom will originate internal waves. On the other hand, it is not known whether energy will be fed back and forth between frequencies as internal waves progress over it. From the standpoint of theory, nonlinear interaction between different kinds of motion and different frequencies is perhaps the greatest gap in present knowledge.

Both modeling and mathematical analyses indicate that internal waves can originate from atmospheric disturbances, but this possibility does not seem to be too well accepted among the investigators. All of these are reasonable theories for the origin of internal waves in 
nonhomogeneous media, but adequate observations to support or discredit any theory are virtually nonexistent.

\section{Existence}

The simplest theory of existence of internal waves is the two-layer theory. This theory assumes a medium composed of two layers of different density. It has become clear that two-layer theory is not adequate to explain observations in the ocean except in a few special places. The special cases are largely confined to northern latitudes where fresh water overlies salt water. The Baltic Sea is a good example, but even in this instance success of the theory is limited.

A more complicated theory, which deals with existence of internal waves in a medium with continuous density distribution, is more realistic. This idea shows that it is mathematically possible for an infinite number of modes of internal waves to exist at any one frequency.

Figure 2 shows the modal distribution computed from data taken at a point off the San Diego coast. The abscissa can be regarded as amplitude in arbitrary units; $M_{1}, M_{2}$, etc., are the various modes. The subscripts indicate the number of the mode. The first-mode wave has a single amplitude maximum, the second mode has two amplitude maxima, and so on. It would be expected that the lower modes in the ocean would be dominant and that the higher modes would be less common because more shear is involved. This theory shows that an infinite number of modes are possible, but does not indicate the amplitudes of the modes. Amplitudes can be established only by computing from observation. Dominant modes are important and should be established, because they probably affect the coherence of waves over space.

Both two-layer theory and continuous-density theory are usually simplified by the assumptions that mean motion is constant from surface to bottom or nonexistent, and that the bottom is a plane; both assumptions are unrealistic. Turbulence, various kinds of surface waves, currents with vertical and horizontal gradients, and other motions are 


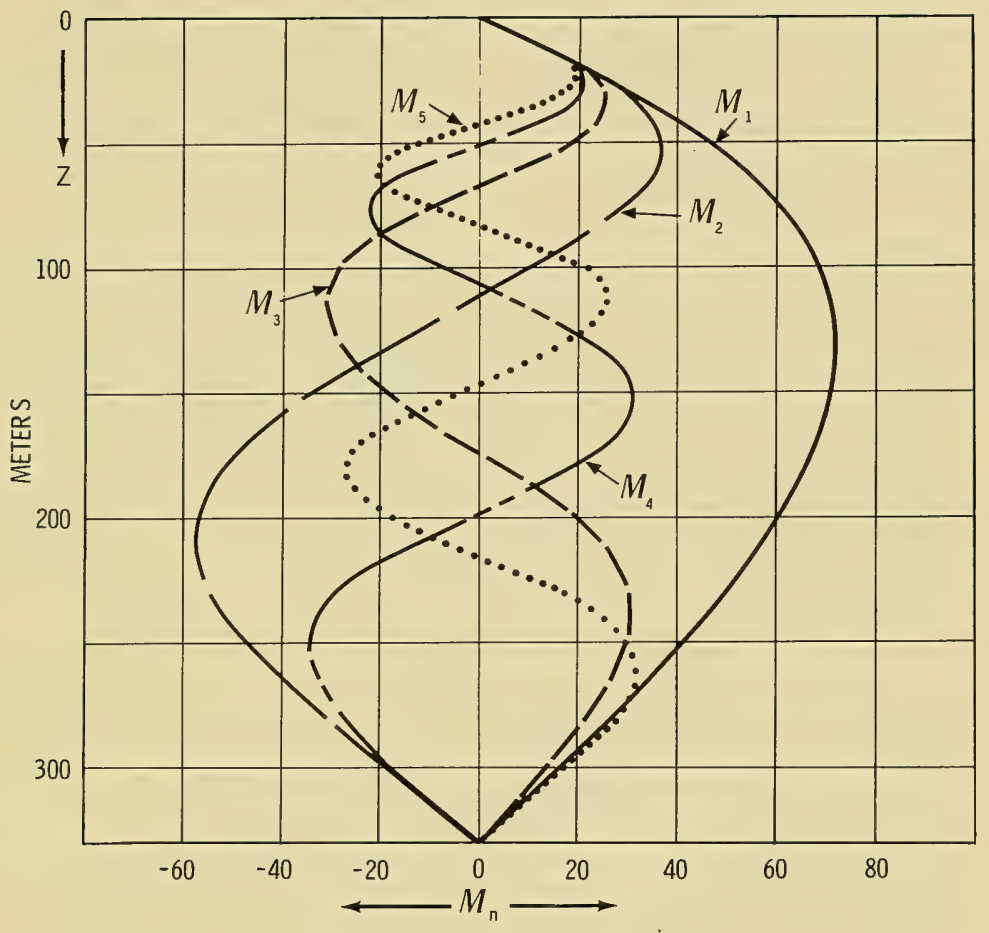

Figure 2. An example of the mode structure of internal waves. Subscripts are the mode numbers.

known to exist. No theory accounts for the interaction between various motions and internal waves, or indeed between internal waves of different frequencies and modes. Linear superposition of different kinds of motion, including internal waves, is probably unrealistic.

Theoretical maximum and minimum frequencies for free internal waves in the ocean have been established within the last two decades. The theoretical maximum frequency is known by various names, the most common being the Väisälä frequency. The theoretical low limits are defined by the Coriolis parameter. The Väisälä frequency is expressed in terms of density, density gradient, 
gravity, and sound velocity in the medium. The maximum frequency is consequently a function of depth. Its maximum occurs in the thermocline, and its lowest value at the depth where density gradient is lowest. Internal perturbations will not progress as a gravity wave at frequencies above the Väisälä frequency. Any internal oscillations at frequencies below the theoretical lowest frequency cannot exist according to the theory as free internal waves.

The phase and group velocity of internal waves is higher for lower-frequency waves. For any given frequency, first-mode internal waves have the highest phase velocity. The phase velocity of the second mode is approximately one-half the phase velocity of the first. The third-mode internal wave progresses at still lower phase velocity, and the phase velocity continues to decrease with higher mode. The mode theory of internal waves indicates that they are highly dispersive waves. Ocean currents modify phase velocity, but have little effect on the modal structure.

Only three unaliased spectra on internal temperature oscillations have been published. A continuous, monotonically decreasing spectrum seems to exist between the minimum and the maximum frequencies, but the relative proportions of variance per bandwidth contributed by internal waves and less regular motion remain unknown. This is an important point that should be emphasized for the benefit of naval operations, because wave motion is easily predictable compared to nonperiodic or transient phenomena.

The effect of rotation of the earth is to increase the amplitude of waves in a direction to the right of the direction of progress, in the northern hemisphere. This effect is apparently unimportant with reference to free internal waves. Rotation also increases the phase velocity compared to the nonrotating case.

Present-day theory on existence of internal plane waves, as opposed to origin or destruction, implies perfect coherence of plane waves over space. According to this theory, an internal wave originating on the coast of Japan travels all the way across the ocean undistorted. If this is true, changes in temperature structure caused by internal waves should be easily predictable for any point in the 
ocean. Although observations of internal waves are generally lacking, studies of coherence by analysis of observed data are perhaps the most important from the standpoint of naval operations.

\section{Destruction}

The literature contains only one report that deals directly with the destruction of internal waves. Instability in a two-layer system depends on densities and velocities of the layers and the wave number. In shallow water where the thickness of both layers is small, instability depends also on their thickness. The criterion for instability is satisfied for values that are observed in the ocean and internal breakers can happen according to this theory.

Time-series observations of temperature at three stations in shallow water off Mission Beach, California, have been recorded for several years. In all these observations only one case has been observed that can be attributed to instability of a progressive internal wave (fig. 3). The instability in this case is more analogous to whitecaps of wind waves than to plunging breakers at the shoreline. Short-period changes in surf temperature can be detected by an attentive swimmer. They might be caused by higherfrequency internal waves such as that shown in figure 3.

Viscosity attenuates motion, and it can be accounted for with slight modification of the equations, but the effect of viscosity seems to be small in the ocean. 


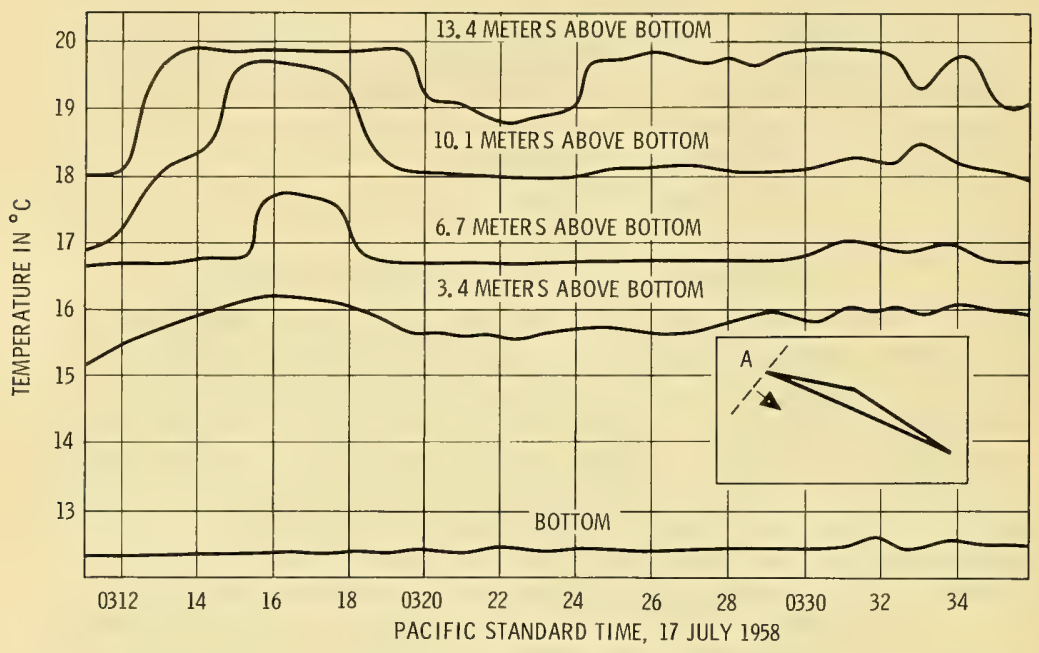

Figure 3A. Observations of temperature at station shown in inset.

Figure 3B. Observations of temperature at station shown in inset. Instability is evidently the unusual result of an internal breaker.

Figure $3 C$. Observations of temperature at station shown in inset. 

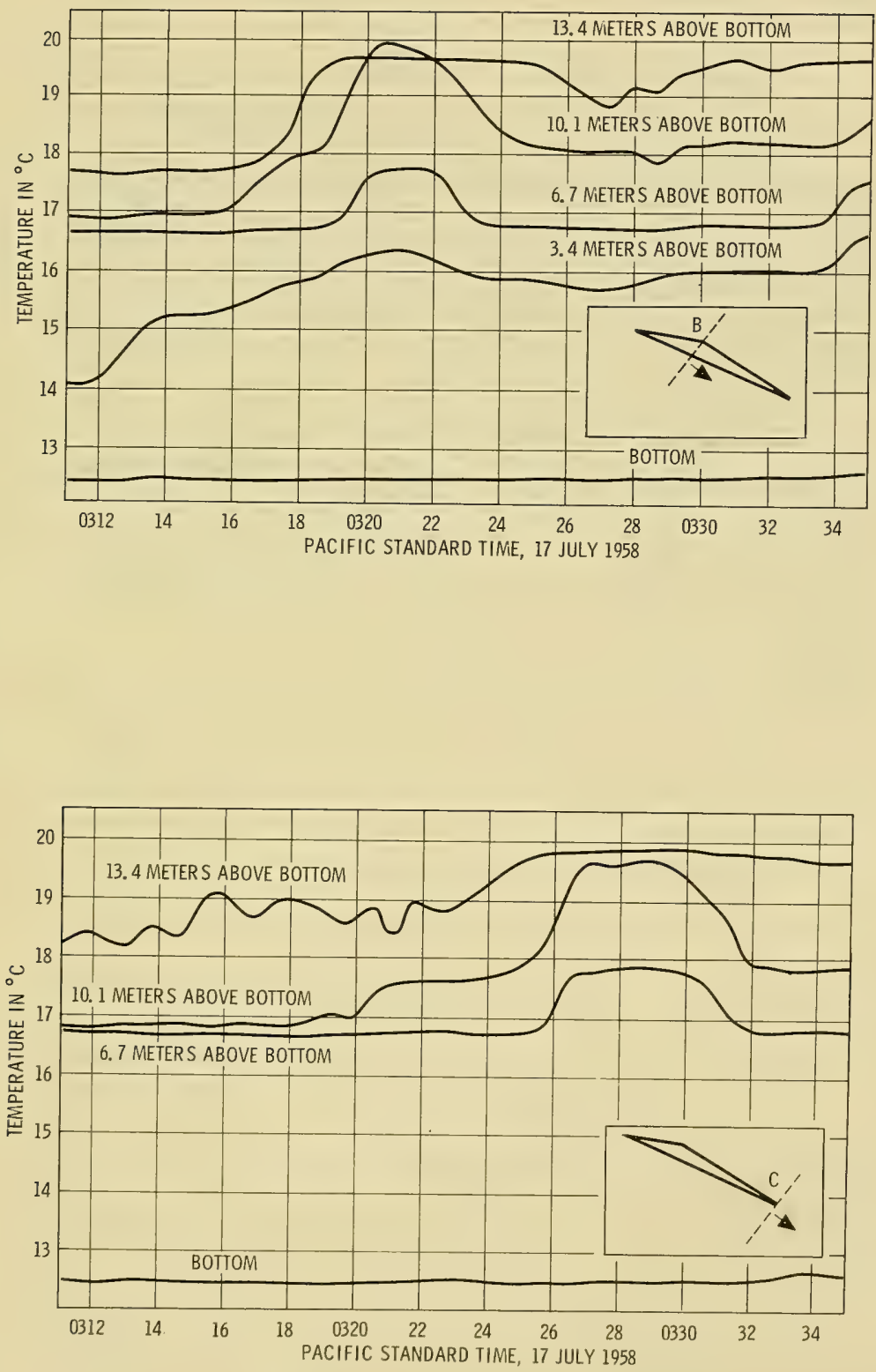


\section{Direction}

Direction of progress is virtually overlooked in the literature. Directionality is important from the standpoint of application to naval operations, because it affects prediction of temperature and density structure. For example, if the progress of internal waves were known to be confined to a very narrow beam width, one would be able to predict the temperature structure, with due consideration for coherence and interactions, at points along a line parallel to the direction of the waves from observations at a point along the line.

Observations in shallow water indicate that internal waves are refracted upon contact with a shoaling bottom. The data also indicate that at least for the higher frequencies no reflection occurs at the shore. Standing internal waves in closed basins have been postulated in order to interpret temperature observations. The evidence is not conclusive in any of these cases. 


\section{SUMMARY}

Internal-wave literature originating in western countries, plus a few papers from Soviet and Chinese works, totals about 350 documents. Most deal with internal sea waves, but a few papers on internal waves in the atmosphere are included to serve as a cross section of the literature. Similar theory applies to both media. The complete bibliography on internal waves in the atmosphere probably would be more extensive than the bibliography on internal waves in the ocean, because meteorology is more advanced than oceanography by several decades. A second consideration is that all pertinent U. S. S. R. and Asian literature is undoubtedly not included here. The language barrier and political conflict hamper communication to such an extent that a comprehensive bibliography on eastern literature would be impossible to compile.

Theory and observation of internal waves are incomplete and largely unrelated. Nonlinear theories of internal waves have been given little attention. Most present theory is kept linear by the neglect of higher-order terms. The theory of infinitesimal waves, very small in amplitude compared to length, is well developed. Finite-amplitude internal waves have been observed on both the west and east coasts of the United States. This directly indicates that a nonlinear theory is necessary for full understanding of internal waves in the ocean.

The equations of motion that govern internal waves are known for a medium with a continuous density distribution over depth and for mean motion that is constant over depth. Solutions of the equations have been obtained for plane boundaries or boundaries of intersecting planes. Solutions have been recently obtained for an irregular bottom by the use of perturbation methods. Internal waves originate by flow over an irregular bottom, by atmospheric disturbances, and possibly by shear flow, and theoretically exist in an infinite number of modes. Free internal waves are confined to a certain band of frequencies. The lower limit of this frequency band confines internal waves to certain limits of latitude, depending on frequency. Some 
objections have been raised to the low-frequency limit, because observations of what are claimed to be free internal waves had been made at higher latitude than the theory would permit.

Increasing awareness of the importance of internal waves in naval operations is apparent among Navy scientists, but it can be developed among the masters of vessels and equipment only through proper instruction. Because present-day knowledge of internal waves is stored in print in so many widely scattered publications, a comprehensive bibliography on internal waves is considered an important bridge to more comprehensive naval research, development, and teaching for Fleet use. 


\section{BIBLIOGRAPHY}

Acoustical Society of America, "Disturbances in a TwoLayer Liquid System," Acoustical Society of America. Journal, v. 33, p. 1631-1632, November 1961

Aichi, K., "Calculation of the Period of the Internal Seiches For Various Lakes and the Sea," Physics-Mathematical Society of Japan. Proceedings, Ser. 2, v. 9, p. 478-485, October 1918

Aichi, K., "On the Internal Seiches," Physics-Mathematical Society of Japan. Proceedings, Ser. 2, v. 9, p. 464-478, October 1918

Arthur, R. S., "Oscillations in Sea Temperature at Scripps and Oceanside Piers," Deep-Sea Research, v. 2, p. 107121,1954

Arthur, R. S., "Variation in Sea Temperature off La Jolla," Journal of Geophysical Research, v. 65, p. 4081-4086, December 1960

Barkhatov, A. N. and Cherkashin, Yu. N., "Deformation of a Beam of Sound by an Internal Wave at the Boundary Between Two Liquids," Soviet Physics: Acoustics, v. 9, p. 86-87, July-September 1963

Barkhatov, A. N. and Cherkashin, Yu. N., "Measurement of the Backscattering of Sound by an Internal Wave," Soviet Physics: Acoustics, v. 8, p. 41-43, July-September 1962

Barkhatov, A. N. and Shmelev, I. I., "Attenuation of a Sound Beam Upon Traversing a Layer of Discontinuity in the Velocity of Sound," Soviet Physics: Acoustics, v. 4, p. 125-127, April-June 1958

Basset, A. B., A Treatise on Hydrodynamics, p. 150-152, Dover, 1961 
Beliakova, O. M. and Beliakov, J. M., "On the Periods of Internal Waves in a Deep Inland Sea," Okeanologiia, v. 3, p. $962-969,1963$

Birge, E. A., "On the Evidence for Temperature Seiches," Wisconsin Academy of Sciences, Arts and Letters. Transactions, v. 16, p. 1005-1016, 1910

Bjerknes, V., "On the Dynamics of the Circular Vortex with Applications to the Atmosphere and Atmospheric Vortex and Wave Motions," Geofysiske Publikationer, v. 2, no. 4, p. 1-89, 1921

Bjerknes, V., "Über Wellenbewegung in kompressiblen schweren Flüssigkeiten, Erste Mitteilung," Akademie der Wissenschaften, Leipzig. Mathematisch-Physische Klasse. Abhandlungen, v. 35, no. 2, 1916

Bjerknes, V. F. K. and others, Physikalische Hydrodynamik, Chapter 8, Springer-Verlag, Berlin, 1933

Bockel, M., "Hydrologie dans le Détroit," p. 325-329 in Peluchon, G., "Traveaux Oceanographiques de 1' 'Origny' a Gibraltar," Cahiers Oceanographiques, v. 14, May 1962

Bolin, B., "The Adjustment of a Non-Balanced Velocity Field Towards Geostrophic Equilibrium in a Stratified Fluid," Tellus; a Quarterly Journal of Geophysics, v. 5, p. $373-3 \overline{85,1953}$

Bolin, B., The Atmosphere and the Sea in Motion, Rockefeller Institute Press, 1959

Boston, N. E. J., Internal Tide Off Panama City, Florida, (Masters Thesis, The Agricultural and Mechanical College of Texas), June 1963

Brunt, D., "The Period of Simple Vertical Oscillations in the Atmosphere," Royal Meteorological Society. Quarterly Journal, v. 53, p. 30-32, 1927 
Bryson, R. A. and Ragotzkie, R. A., "On Internal Waves in Lakes," Limnology and Oceanography, v. 5, p. 397408, October 1960

Burnside, W., "On the Small Wave-Motions of a Heterogeneous Fluid Under Gravity," London Mathematical Society. Proceedings, v. 20, p. $392-397,1889$

Cahn, A., Jr., "An Investigation of the Free Oscillations of a Simple Current System," Journal of Meteorology, v. 2, p. 113-119, June 1945

Canada. Directorate of Scientific Information Services Translation T 101 G, Internal Waves, by J. E. Fjeldstad, May 1961

Canada. Pacific Naval Laboratory, Esquimalt, British Columbia Technical Memorandum 56-2, The Creation and Propagation of Internal Waves; a Literature Survey, by P. A. Davis and A. M. Patterson, 30 May 1956

Canada. Pacific Oceanographic Group File N 7-19-2, Internal Waves in Georgia Strait, by J. A. Shand, 1 April 1953

Carsola, A. J. and Callaway, E. B., "Two Short-Period Internal Wave Frequency Spectra in the Sea Off Southern California," Limnology and Oceanography, v. 7, p. 115120, April 1962

Carsola, A. J., Hamm, D. P., and Roque, J. C., "Internal Waves over Banks and Basins off Southern California (Abstract)," p. VI-129 in International Union of Geodesy and Geophysics General Assembly, 13th, 19-31 August 1963, Abstracts of Papers, Berkeley, 1963

Cartwright, D. E., "On Submarine Sand-Waves and Tidal Lee-Waves," Royal Society of London. Proceedings. Series A: Mathematical and Physical Sciences, v. 253, p. 218-241, 24 November 1959 
Case, K. M., "Stability of an Idealized Atmosphere, I: Discussion of Results," Physics of Fluids, v. 3, p. 149154, March-April 1960

Chicago University. Institute of Meteorology Miscellaneous Report 23, Theory of Perturbations in Stratified Currents With Application to Airflow over Mountain Barriers, by P. Queney, 1947

Chien-P'ing, S., "Determination of the Elements of Internal Waves by Single Hydrographical Observations at Sea," Academy of Sciences, U.S.S.R. Bulletin. Geophysics Series, p. 717-719, July 1961

Coker, R. E., This Great and Wide Sea, p. 154-156, University of North Carolina Press, 1947

Columbia University. Hudson Laboratories Contract N6ONR-27135 Technical Report 59, Temperature Studies of Internal Waves, by T. Arase and others, 14 November 1958

Cooper, L. H. N., "Internal Waves and Upwelling of Oceanic Water From Mid-Depths on to a Continental Shelf," Nature, v. 159, p. 579-580, 26 April 1947

Cox, C. S., "Coupling of Surface and Internal Tides," p. 399-400 in International Oceanographic Congress, New York, 1959. Preprints of Abstracts of Papers to be presented at Afternoon Sessions; Edited by Mary Sears, American Association for the Advancement of Science, 1959

Cox, C. S., "Internal Waves," American Geophysical Union. Transactions, v. 44, p. 488-489, June 1963

Cox, C. S., "Internal Waves, Part 2," p. 752-763 in M. N. Hill, The Sea, v. 1, Interscience, 1962

Cox, C. S., "Measuring Internal Waves," Journal of Geophysical Research, v. 66, p. 1553, May 1961 
Cox, C. S., "Moored Station Type C," p. 16-19 in Scripps Institution of Oceanography Reference 60-50, Scripps Tuna Oceanography Research (STOR) Program, 5 August 1960

Cox, C. and Sandstrom, H., "Coupling of Internal and Surface Waves in Water of Variable Depth," Oceanographical Society of Japan. Journal, v. 20, p. 499-513, 1962

Crease, J., "Internal Waves," p. 129-138 in Institute on Underwater Acoustics, London, 1961. Underwater Acoustics; Proceedings of an Institute... July 31 - August 11, 1961, Edited by V. M. Albers, Plenum Press, 1963

Crease, J., "The Propagation of Long Waves Into a SemiInfinite Channel in a Rotating System," Journal of Fluid Mechanics, v. 4, p. 306-320, July 1958

* Defant, A., "Bericht über Kurzperiodische Schwangungen von Temperatur und Salzgehalt in den Obersten Wasserschlichten des Ozeans," Gesellschaft für Erdkunde zu Berlin. Zeitschrift, p. 286-300, 1927

Defant, A., Ebb and Flow, p. 99-105, University of Michigan Press, 1958

Defant, A., "Flutwellen und Gezeiten des Wassers," p. 846-927 in Handbuch der Physik, v. 48: Geophysik 2, Berlin, Springer, 1957

Defant, A., "Gedanken über Interne Gezeitenwellen," p. 310315, James Johnstone Memorial Volume, Liverpool, 1934

Defant, A., Die Gezeiten und Inneren Gezeitenwellen des Atlantischen Ozeans; Ergebnisse der Strom-und Serienmessungen auf den Ankerstationen des "Meteor" [Deutsche Atlantische Expedition auf dem Forschungs-und Vermessungsschiff "Meteor" 1925-1927. Bd. VII, I Teil], Berlin, Gruyter, 1932

* Not verified 
Defant, A., "Internal Waves," p. 517-570 in A. Defant, Physical Oceanography, v. 2, Pergamon Press, 1961

Defant, A., "The Origin of Internal Tide Waves in the Open Sea," Journal of Marine Research, v. 9, p. 111-119, 1950

Defant, A., "Die Ozeanographischen Arbeiten auf der Ersten Teilfahrt der Deutschen Nordatlantischen Expedition des 'Meteor', Februar bis Mai 1937," Annalen der Hydrographie und Maritimen Meteorologie, v. 65, p. 6-14, September Beiheft, 1937

Defant, A., "Die Ozeanographischen Verhältnisse Während der Ankerstation des 'Altair' am Nordrand des Hauptstromstriches des Golfstromes Nördlich der Azoren," Annalen der Hydrographie und Maritimen Meteorologie, v. 68, p. 1-34, November Beiheft, 1940

Defant, A., Physical Oceanography, v. 2, p. 517-570, Pergamon Press, 1961

Defant, A., "Reality and Illusion in Oceanographic Surveys," Journal of Marine Research, v. 9, p. 120-138, 1950

Defant, A., "Scylla und Charybdis und die Gezeitenströmungen in der Strasse von Messina," Annalen der Hydrographie und Maritimen Meteorologie, v. 68, p. 145157,1940

Defant, A., "Strommessungen und Ozeanographische Serienbeobachtungen der Vier-Länder-Unternehmung im Kattegatt 10 - 17 August 1931," Berlin. Universität. Institut für Meereskunde. Veröffentlichungen. Series A. Geographisch-Naturwissenschaftliche Reihe, v. 25, p. 360, April 1934

Defant, A., "Über Interne Gezeitenwellen und Ihre Stabilitätsbedingungen," Archiv für Meteorologie, Geophysik, und Bioklimatologie, Ser. A, v. 1, p. 39-61, 1948-1949 
Defant, A., "Über Interne Wellen, Besonders Solche Mit Gezeitencharakter," Deutsche Hydrographische Zeitschrift, v. 5, p. $231-245,1952$

Demoll, R., "Temperaturwellen (=Seiches) und Planktonwellen," Archiv für Hydrobiologie, v. 13, p. 313320,1922

* Deryugin, K. M., "On Internal Waves in the Eastern Part of the Gulf of Finland," Hydrological Conference of the Baltic States, v. 3, 1933

Dietrich, G., General Oceanography, p. 384-393, Interscience Publishers, 1963

Dikii, L. A., "On the Stability of Plane Parallel Flows of an Inhomogeneous Fluid," Applied Mathematics and Mechanics, v. 24, p. 357-369, 1960

Drazin, P. G., "The Stability of a Shear Layer in an Unbounded Heterogeneous Inviscid Fluid," Journal of Fluid Mechanics, v. 4, p. 214-224, June 1958

Eckart, C. H., Hydrodynamics of Oceans and Atmospheres, Pergamon, 1960

Eckart, C., "Internal Waves in the Ocean," Physics of Fluids, v. 4, p. 791-799, July 1961

Ekman, V. W., "On Dead Water," in Nansen, F., Ed., The Norwegian North Polar Expedition, 1893-1896;

Scientific Results, v. 5, no. 15, Longmans Green, 1906

Ekman, V. W., "On Internal Waves," International Council for the Exploration of the Sea, Rapports et Procès Verbaux des Reunions, v. 76, p. 5-31, 1931

* Not verified 
Eliassen, A., Hфiland, E., and Riis, E., "Two-

Dimensional Perturbation of a Flow with Constant Shear of a Stratified Fluid," Norske Videnskaps-Akademi i Oslo. Institutt for Vaer- og Klimaforskning. Publication, no. 1, p. $1-30,1953$

Eliassen, A. and Palm, E., "On the Transfer of Energy in Stationary Mountain Waves," Geofysiske Publikasjoner, v. 22, p. 1-23, September 1961

Emery, K. O., "Deep Standing Internal Waves in California Basins," Limnology and Oceanography, v. 1, p. 35-41, January 1956

Ewing, G., "Slicks, Surface Films and Internal Waves," Journal of Marine Research, v. 9, p. 161-187, December 1950

Ewing, G. C., "Relation Between Band Slicks at the Surface and Internal Waves in the Sea," Science, v. 111, p. $91-94,27$ January 1950

Exner, F., "Ergebnisse Einiger Temperaturregistrierungen im Wolfgangsee," Akademie der Wissenschaften, Vienna. Mathematisch-Naturwissenschaftliche Klasse. Sitzungsberichte, v. 117, IIa, p. 1295-1315, 1908

Exner, F., "Über Eigentümliche Temperaturschwankungen von Eintägiger Periode im Wolfgangsee," Akademie der Wissenschaften, Vienna. Mathematisch-Naturwissenschaftliche Klasse. Sitzungsberichte, v. $117 \mathrm{IIa}$, p. 9-26, 1908

Exner, F., "Über Temperaturseiches im Lunzer See," Annalen der Hydrographic und Maritimen Meteorologie, v. 56, p. $14-20,1928$

Exner, F. M., "Zur Frage der Temperaturseiches I," Petermanns Geographische Mitteilungen, v. 56, p. 139, 1910

Fjeldstad, J. E., "Influence of Eddy Viscosity on Internal Waves," International Association of Physical Oceanography. Procès-Verbaux, v. 7, p. 61-63, 1957 
Fjeldstad, J. E., "Interne Wellen," Geofysiske Publikasjoner, v. 10, No. 6, p. 1-35, 1933

Fjeldstad, J. E., "Interne Wellen," International

Geographic Congress. 12th Congress. Comptes-Rendus, v. 12 , sec. 2 b, p. 49,1938

Fjeldstad, J. E., "Measurements of Internal Waves," International Association of Physical Oceanography. Procès-Verbaux, No. 5, Brussels, p. 174-176, August 1951

Fjeldstad, J. E., "Observations of Internal Tidal Waves," p. 39-45 in U. S. National Bureau of Standards. Proceedings of the NBS Semicentennial Symposium on Gravity Waves Held at the NBS on June 18-20, 1951, U. S. Government Printing Office, 1952

Fjeldstad, J. E., "Ocean Current as an Initial Problem," Geofysiske Publikasjoner, v. 20, No. 7, p. 1-24, June 1958

Fjeldstad, J. E., "Results of Tidal Observations," v. 4, no. 4 of Norwegian North Polar Expedition with the "Maud," 19181925, Scientific Results, Bergen, J. Griegs, 1936

Florida State University. Oceanographic Institute Technical Paper 1, Annotated Bibliography on Internal Waves, by T. Ichiye, July 1962

Florida State University. Oceanographic Institute Technical Report 3, Internal Waves Over a Continental Shelf, by T. Ichiye, February 1963 (Unpublished Manuscript)

Frassetto, R., "A Preliminary Survey of Thermal Microstructure in the Strait of Gibraltar," Deep-Sea Research, v. 7, p. $152-162,1960$

Freeman, J. C., Jr., "Note on a Prediction Equation For the Surface Layer of a Two-Layer Ocean," American Geophysical Union. Transactions, v. 35, p. 585-587, August 1954 
Fukuoka, J., "On the Periodicity of the Variations of the Oceanic Conditions," Marine Meteorological Society. Journal, v. 35, p. $13-20,1959$

Gaul, R. D., "Observations of Internal Waves Near Hudson Canyon," Journal of Geophysical Research, v. 66, p. 3821 3830, November 1931

Gaul, R. D., "The Travel of Internal Temperature Fluctuations at Texas Tower 4 (Abstract)," Journal of Geophysical Research, v. 66, p. 2531, August 1961

Germany. Kiel University. Institut für Meereskunde, The Model of an Observational Mast, by G. Dietrich and W. Krauss, 1959

Glinsky, N. T., "On the Internal Waves in the North Atlantic," Okeanologiya, v. 3, p. 13-17, 1963

Glinskii, N. T., "On the Vertical Fluctuations of the Water Temperature in the Black Sea," Akademiia Nauk, S.S.S.R. Izvestiia. Seriia Geofizicheskaia, No. 6, p. 688-697, May 1960

Goldstein, S., "On the Stability of Superposed Streams of Fluids of Different Densities," Royal Society of London. Proceedings. Series A: Mathematical and Physical Sciences, v. 132, p. 524-528, 1931

Görtler, H., "Einfluss der Bodentopographie auf Strömungen über der Rotierenden Erde," Seitschrift für Angewandte Mathematik und Mechanik, v. 21, p. 279-303, 1941

Görtler, H., "Neuere Beiträge zur Dynamik Atmosphärischer und Ozeanischer Strömungen," Naturwissenschaften, v. 29, p. $473-479,1941$

Görtler, H., "Strömungen über Bodenerhebungen auf der Rotierenden Erde," Meteorologische Zeitschrift, v. 59, p. $405-410,1942$ 
Görtler, H., "Über Eine Schwingungserscheinung in Flüssigkeiten mit Stabiler Dichteschichtung," Zeitschrift für Angewandte Mathematik und Mechanik, v. 23, p. 65-71, 1943

Gossard, E. E., "Internal Waves in the Lower Atmosphere and Their Effect on Radar Propagation," p. 444-453 in Office of Naval Research ONR-2, A Decade of Basic and Applied Science in the Navy, 19-20 March 1957

Gossard, E. E., "The Reflection of Microwaves by a Refractive Layer Perturbed by Waves," Institute of Radio Engineers. Transactions: Antennas and Propagation, v. AP-10, p. 317-325, May 1962

Gossard, E. E., "Vertical Flux of Energy into the Lower Ionosphere From Internal Gravity Waves Generated in the Troposphere," Journal of Geophysical Research, v. 67 , p. 745-757, February 1962

Gossard, E. and Munk, W., "Gravity Waves in the Atmosphere," Royal Meteorological Society. Quarterly Journal, v. 81, p. 484-487, 1955

Gossard, E. and Munk, W., "On Gravity Waves in the Atmosphere," Journal of Meteorology, v. 11, p. 259-269, 1954

Great Britain. Admiralty. Department of Research Programmes and Planning ACSIL Translation 561, Internal Waves in the Kattegat, by B. Kullenberg, September 1952

Greenhill, A. G., "Wave Motion in Hydrodynamics," American Journal of Mathematics, v. 9, p. 62-112, 1887

Groan, P., "Contribution to the Theory of Internal Waves," Koninklijk Nederlands Meteorologisch Instituut de Bilt. Mededelingen en Verhandelingen, Ser. B, v. 2, No. 11, 1948 
Groen, P., "Two Fundamental Theorems on Gravity Waves in Inhomogeneous Incompressible Fluids," Physica, v. 14, p. 294-300, June 1948

Halbfass, W., "Zur Frage der Temperaturseiches," Petermanns Geographische Mitteilungen, v. 55, p. 364365,1909

Halbfass, W., "Zur Frage der Temperaturseiches II," Petermanns Geographische Mitteilungen, v. 56, p. 139, 1910

Harrison, W. J., "The Influence of Viscosity on the Oscillations of Superposed Fluids," London Mathematical Society. Proceedings, Ser. 2, v. 6, p. 396-405, 30 April 1908

Harvard University. Engineering and Applied Science Division, Internal Wave Generation by a Moving Object, by G. F. Carrier and P. Bakshi, September 1963

Haurwitz, B., "The Effect of Gradual Wind Change on the Stability of Waves," New York Academy of Sciences. Annals, v. 44, p. $69-80,1943$

Haurwitz, B., "The Effect of Ocean Currents on Internal Waves," Journal of Marine Research, v. 7, p. 217-228, November 1948

Haurwitz, B., "Internal Waves in the Atmosphere and Convection Patterns," New York Academy of Sciences. Annals, v. 48, p. $727-744,1947$

Haurwitz, B., "Internal Waves of Tidal Character," American Geophysical Union. Transactions, v. 31, p. 4752, February 1950

Haurwitz, B., "The Occurrence of Internal Tides in the Ocean," Archiv für Meteorologie, Geophysik und Bioklimatologie, Ser. A, v. 7, p. 406-424, 1954 
Haurwitz, B., "Zur Theorie der Wellenbewegungen in Luft und Wasser," Leipzig. Universität. Geophysikalisches Institut. Veröffentlichungen, v. 5, p. 1-106, 1931

Haurwitz, B. and others, "On the Thermal Unrest in the Ocean," p. 74-94 in Bolin, B., The Atmosphere and the Sea in Motion, Rockefeller Institute Press, 1959

Hela, I. and Krauss, W., "Zum Problem der Starken Veränderlichkeit der Schichtungsverhältnisse im ArkonaBecken," Kieler Meersforschungen, v. 15, p. 125-143, 1959

Helland-Hansen, B., "Investigations of the Local and Temporal Fluctuations of the Gulf Stream in the Norwegian Sea," Norsk Geografisk Tidsskrift, v. 7, p. 407-419, $1938-1939$

Helland-Hansen, Bj., "Physical Oceanography and Meteorology," v. 1, p. 1-115 in Michael Sars Expedition, 1910, Report on the Scientific Results of the "Michael Sars" North Atlantic Deep-Sea Expedition, 1910, Bergen, J. Griegs, 1930

Helland-Hansen, B., "The Sognefjord Section; Oceanographic Observations in the Northernmost Part of the North Sea and the Southern Part of Norwegian Sea," p. 257-274, James Johnstone Memorial Volume, Liverpool, 1934

Helland-Hansen, B. and Nansen, F., "The Eastern North Atlantic," Geofysiske Publikasjoner, v. 4, p. 1-76, Plates 1-71, 1927

Helland-Hansen, B. and Nansen, F., "The Norwegian Sea," p. 87-132 in Norway. Fiskeridirektoratet, Report on Norwegian Fishery and Marine Investigations, v. 2, 1909

Helmholtz, H., "Über Discontinuierliche Flüssigkeitsbewegungen," Akademie der Wissenschaften, Berlin. Monatsberichte, p. 215-228, 1868 
Heyna, B. and Groen, P., "On Short-Period Internal Gravity Waves," Physica, v. 24, p. 383-389, May 1958

Hines, C. O., "An Interpretation of Certain Ionospheric Motions in Terms of Atmospheric Waves," Journal of Geophysical Research, v. 64, p. 2210-2211, December 1959

Hoiland, E., "On the Dynamic Effect of Variation in Density on Two-Dimensional Perturbations of Flow With Constant Shear," Geofysiske Publikasjoner, v. 18, p. 112, 1953

Hфiland, E., "On the Effect of Variation in Gravitational Stability in a Linear Fluid Flow," Norske VidenskapsAkademi i Oslo. Institutt vor Vaer-og Klimaforskning. Report, no. 3, p. 1-9, 1953

Hфiland, E., "On the Wave Motions in Sliding Layers With Internal Static Stability," Archiv för Mathematik og Naturvidenskab, v. 47, p. 41-72, 1943

Howard, L. N., "Note on a Paper of John W. Miles," Journal of Fluid Mechanics, v. 10, p. 509-512, June 1961

Hudimac, A. A., "Ship Waves in a Stratified Ocean," Journal of Fluid Mechanics, v. 11, p. 229-243, 1961

Hydrographic Office H. O. Miscellaneous 15360, Effects of Weather Upon the Thermal Structure of the Ocean, Progress Report 1, by J. J. Schule, Jr., 1952

Hydrographic Office Technical Report 26, Power Spectrum Analysis of Internal Waves from Operation STANDSTILL, by A. L. Brown and others, October 1955

Hydrographic Office Technical Report 94, Tongue of the Ocean Research Experiment, by A. W. Magnitzky and H. V. French, 1960 
Hydrographic Office Technical Report 107, The Occurrence and Velocity Distribution of Short-Term Internal Temperature Variations Near Texas Tower No. 4, by R. D. Gaul, May 1964

Hydrographic Office Translation 92, Oscillations of Stability and the Internal Thermal Agitation in the Sea and in the Atmosphere, by G. Neumann, 1960

Iampol'skii, A. D., "On Internal Waves in the North Atlantic," Akademiia Nauk SSSR. Institut Okeanologii. Trudy, v. 56, p. 229-240, 1962

Ichiye, T., "On Stationary Internal Waves Caused by Bottom Configuration," Oceanographical Society of Japan. Journal, v. 6, p. 1-7, 1950

Ippen, A. T. and Harleman, D. R. F., "Steady-State Characteristics of Subsurface Flow," p. 79-93 in U. S. National Bureau of Standards. Proceedings of the NBS Semicentennial Symposium on Gravity Waves Held at the NBS on June 18-20, 1951, U. S. Government Printing Office, 1952

Iwata, N., "Effect of Ocean Current on Internal Waves in the Open Ocean," Oceanographical Society of Japan. Journal, v. 18, p. 236-249, 1962

Iwata, N., "Sur les Ondes Internes Dans la Mer en Rapport Avec le Détroit de Gibraltar," Cahiers Océanographiques, v. 15, p. 236-249, April 1963

Jacobs, W. C., "Atmospheric Waves on Isentropic Surfaces as Evidenced by Interfrontal Ceiling Oscillations," Monthly Weather Review, v. 65, p. 9-12, January 1937

Jacobsen, J. P. and Thomsen, H., "Periodical Variations in Temperature and Salinity in the Straits of Gibraltar," p. 275-293, James Johnstone Memorial Volume, Liverpool, 1934 
Kajiura, K., "Note on the Generation of Boundary Waves of Kelvin Type," Oceanographical Society of Japan. Journal, v. 18, p. $49-58,1962$

Kalle, K., "Über die Innere Thermische Unruhe des Meeres," Annalen der Hydrographic und Maritimen Meteorologie, v. 70, p. 383-387, December 1942

Kalle, K., "Zur Frage der Inneren Thermischen Unruhe des Meeres," Deutsche Hydrographische Zeitschrift, v. 6, p. $145-170,1953$

Kampe, H. J. aufm, "Über Schwebeballon-Vermessungen im Lee der Rossittener Wanderdüne und einige Allgemeine Bemerkungen über Schwingungen in der Freien Atmosphäre," Beiträge zur Physik der Freien Atmosphäre, v. 26, p. 107118,1940

Keulegan, G. H., "Characteristics of Internal Solitary Waves," Journal of Research of the National Bureau of Standards, v. 51, p. 133-140, September 1953

Keulegan, G. H., "Interfacial Instability and Mixing in Stratified Flows," Journal of Research of the National Bureau of Standards, v. 43, p. 487-500, November 1949

Kiel University Institut für Meereskunde, Model of an Observational Mast, by G. Dietrich and W. Krauss, 1959

Kierstead, H. A., "Bottom Pressure Fluctuations Due to Standing Waves in a Deep, Two-Layer Ocean," American Geophysical Union. Transactions, v. 33, p. 390-396, June 1952

Knauss, J. A., "Observations of Internal Waves of Tidal Period Made With Neutrally-Buoyant Floats," Journal of Marine Research, v. 20, p. 111-118, July 1962

Knauss, J. A., "Observations of Irregular Motion in the Open Ocean," Deep-Sea Research, v. 7, p. 68-69, 1960 
Konaga, S., "Kuroshio in Enshū-nada, (III): Variations of the Depth of Isotherms," Oceanographical Magazine, v. 13, p. 31-40, October 1961

Kononkova, G. E. and Kontoboitseva, N. V., "Temperature Oscillations in the Surface Layer of the Sea Caused by Wave Movement," Academy of Sciences U.S.S.R. Bulletin, Geophysics Series, v. 12, p. 57-64, 1957

Kotchine, N., "Détermination Rigoureuse des Ondes Permanentes d'Ampleur Finie à la Surface de Séparation de Deux Liquides de Profondeur Finie," Mathematische Annalen, v. 98, p. 582-615, 1928

Krauss, W., "Interne Wellen Grosser Amplitude- Teil 1, Eigenschwingungen der Grenzfläche Zweier Wassermassen im Reibungsfreien Ozean," Deutsche Hydrographische Zeitschrift, v. 10, p. 191-201, 1957

Krauss, W., "Interne Wellen Grosser Amplitude- Teil 2, Beobachtungen," Deutsche Hydrographische Zeitschrift, v. 11, p. $194-207,1958$

Krauss, W., "Interne Wellen Grosser Amplitude- Teil 3, Kritik der Theorien und der Beobachtungen," Deutsche Hydrographische Zeitschrift, v. 11, p. 246-255, 1958

Krauss, W., "Meteorologically Forced Internal Waves in the Region Southwest of Iceland," International Council for the Exploration of the Sea, Rapports et Procès Verbaux des Reunions, v. 149, p. 89-92, 1961

Krauss, W., "Spectra of Internal Waves in a Stratified Water Mass and Their Interpretations (Abstract)," p. VI128 in International Union of Geodesy and Geophysics General Assembly, 13th, 19-31 August 1963, Abstracts of Papers, Berkeley, 1963 
Krauss, W., "The Spectra of Turbulence and Internal Waves in the Baltic Sea," p. 766-782 in National Coastal and Shallow Water Research Conference, First. Proceedings, Tallahassee, 1961

Kraus, W., "The Spectra of Turbulence and Internal Waves in the Baltic Sea," p. 375-384 in Symposium on MathematicalHydrodynamical Methods of Physical Oceanography. Proceedings, Hamburg University. Institut für Meereskunde, September 1961

Krauss, W., "Theorie der Internen Mitschwingungswellen," Kieler Meeresforschungen, v. 15, p. 3-16, 1959

Krauss, W., "Über den Einfluss der Erdrotation auf Interne Wellen," Kieler Meeresforschungen, v. 17, p. 816,1961

Krauss, W., "Über Meteorologisch Bedingte Interne Wellen auf Einer Dauerstation Südwestlich Islands," Deutsche Hydrographische Zeitschrift, Ergänzungsheft Reihe B( $\left.4^{\circ}\right)$, no. 3, p. 55-58, 1959

Krauss, W., "Zum System der Internen Seiches der Ostsee," Kieler Meeresforschungen, v. 19, p. 119-132, 1963

Krauss, W., "Zur Trochoidenähnlichen Form der' Kurzen Fortschreitender Internen Grenzflächenwellen," Keiler Meeresforschungen, v. 17, p. 159-162, 1961

Krauss, W., and Magaard, L., "Zum Spektrum der Internen Wellen der Ostsee," Kieler Meeresforschungen, v. 17, p. $137-147,1961$

LaFond, E. C., "Boundary Effects on the Shape of Internal Temperature Waves," Indian Journal of Meteorology \& Geophysics, v. 12, p. 335-338, April 1961 
LaFond, E. C., "Factors Affecting Vertical Temperature Gradients in the Upper Layers of the Sea," Scientific Monthly, v. 78, p. 243-253, April 1954

LaFond, E. C., "Internal Wave Motion and Its Geological Significance," p. 61-77 in Mahadevan Volume, A Collection of Geological Papers in Commemoration of the Sixty-First Birthday of Prof. C. Mahadevan, Osmania University Press, 6 May 1961

LaFond, E. C., "Internal Waves," p. 731-751 in M. N. Hill, The Sea, v. 1, Interscience, 1962

LaFond, E. C., "Sea Surface Features and Internal Waves in the Sea," Indian Journal of Meteorology and Geophysics, v. 10 , p. $415-419$, October 1959

LaFond, E. C., "Sea Surface Slicks and Related Phenomena," p. 763-766 in International Oceanographic Congress, New York, 1959. Preprints of Abstracts of Papers to be Presented at Afternoon Sessions; Edited by Mary Sears, American Association for the Advancement of Science, 1959

LaFond, E. C., "Three-Dimensional Temperature Structure of the Upper 800 Feet of the Sea (Abstract)," p. VI-138 in International Union of Geodesy and Geophysics General Assembly, 13th, 19-31 August 1963, Abstracts of Papers, Berkeley, 1963

LaFond, E. C., "Water Motions Associated With Internal Waves," p. 530 in National Coastal and Shallow Water Research Conference, First. Proceedings, Tallahassee, 1961

LaFond, E. C. and Lee, O. S., "Internal Waves in the Ocean," Navigation, v. 9, p. 231-236, Autumn 1962

LaFond, E. C. and Poornachandra Rao, C., "Vertical Oscillations of Tidal Periods in the Temperature Structure of the Sea," Andhra University. Memoirs in Oceanography, v. 1, p. 109-116, 1954 
Lamb, H., Hydrodynamics, 6th ed., p. 370-375, Dover, 1945

Lamb, H., "On Waves Due to a Travelling Disturbance, With an Application to Waves in Superposed Fluids," Philosophical Magazine, Series 6, v. 31, p. 386-399, April 1916

Lee, O. S., "Effect of an Internal Wave on Sound in the Ocean," Acoustical Society of America. Journal, v. 33, p. 677-681, May 1961

Lee, O. S., "Observations on Internal Waves in Shallow Water," Limnology and Oceanography, v. 6, p. 312-321, July 1961

Lee, O. S. and Batzler, W. E., "Fixed Path Acoustic Transmission in the Presence of Internal Waves (Abstract)," Acoustical Society of America. Journal, v. 32, p. 1514, November 1960

Leipper, D. F., "Sea Temperature Variations Associated With Tidal Currents in Stratified Shallow Water Over an Irregular Bottom," Journal of Marine Research, v. 14, no. 3, p. 234-252, 1955 .

Lek, D. L., "Interne Wellen in Den Niederlandischostindischen Gewässern," International Geographic Congress. 12 th Congress. Comptes-Rendus, v. 12, sec. 2b, p. 6976,1938

Lek, L., "Die Ergebnisse der Strom-und Serienmessungen," Pt. 3 in the Snellius Expedition in the Eastern Part of the Netherlands East-Indies, 1929-1930, Reports, v. 2:

Oceanographic Results, Leiden, E. J. Brill, 1938

Lisitzin, E., "On Internal Waves in the Northern Baltic," Finland. Havsforsknings-Institutet. Havsforsknings Institutets Skrifter, no. 161, p. 1-9, 1953 
Lockheed-California Company Report 16795, Spectra of Internal Waves Over Basins and Banks Off Southern California, by A. J. Carsola and others, March 1963

Long, R. R., "A Laboratory Model Resembling the 'BishopWave' Phenomenon," American Meteorological Society. Bulletin, v. 34, p. 205-211, May 1953

Long, R. R., "Long Waves in a Two-Fluid System," Journal of Meteorology, v. 13, p. 70-74, February 1956

Long, R. R., "The Motions of Fluids With Density Stratification," Journal of Geophysical Research, v. 64, p. 2151-2163, December 1959

Long, R. R., "Solitary Waves in the One- and Two-Fluid Systems," Tellus; a Quarterly Journal of Geophysics, v. 8, p. 460-471, November 1956

Long, R. R., "Some Aspects of the Flow of Stratified Fluids. I. A Theoretical Investigation," Tellus; a Quarterly Journal of Geophysics, v. 5, p. 42-58, 1953

Long, R. R., "Some Aspects of the Flow of Stratified Fluids, II: Experiments With a Two-Fluid System," Tellus; A Quarterly Journal of Geophysics, v. 6, p. 97115, May 1954

Long, R. R., "Some Aspects of the Flow of Stratified Fluids, III: Continuous Density Gradients," Tellus; a Quarterly Journal of Geophysics, v. 7, p. 341-347, August 1955

Love, A. E. H., "Wave Motion in a Heterogeneous Heavy Liquid," London Mathematical Society. Proceedings, v. 22 , p. 307-316, 1891

Lyra, G., "Theorie der Stationären Leewellenströmung in Freier Atmosphäre," Zeitschrift für Angewandte Mathematik und Mechanik, v. 23, p. 1-28, February 1943 
Lyra, G., "Über den Einfluss der Bodenerhebungen auf die Strömung einer Stabil Geschichteten Atmosphäre,"

Beiträge zur Physik der Freien Atmosphäre, v. 26, p. 197206,1940

Magaard, L., "Zur Berechnung Interner Wellen in Meeresräumen mit Nicht-Ebenen Böden Bei Einer Speziellen Dichteverteilung, "Kieler Meeresforschungen, v. 18, p. 161183,1962

* Makkaweev, W., "Bemerkungen über die Theorie der Langen Internen Wellen," Hydrological Conference of the Baltic States, Helsinki, v. 15, p. 13-19, June 1936

Malkus, J. S. and Stern, M. E., "The Flow of a Stable Atmosphere Over a Heated Island, Part 1," Journal of Meteorology, v. 10, p. 30-41, February $195 \overline{3}$

Malyuzhinets, G. D., "Sound Scattering by Nonuniformities in a Layer of Discontinuity in the Sea," Soviet Physics: Acoustics, v. 5, p. 68-74, January-March 1959

Masuzawa, J., "A Short-Period Fluctuation of the Kuroshio East of Cape Kinkazan," Oceanographical Magazine, v. 10, p. 1-8, June 1958

Miles, J. W., "On The Stability of Heterogeneous Shear Flows," Journal of Fluid Mechanics, v. 10, p. 496-508, June 1961

Mortimer, C. H., "The Use of Models in the Study of Water Movements in Stratified Lakes," p. 254-260 in International Association of Theoretical and Applied Limnology,

Proceedings, v. 11, Stuttgart, E. Schweizerbart, 1951

Mortimer, C. H., "Water Movements in Lakes During Summer Stratification; Evidence From the Distribution of Temperature in Windermere," Royal Society of London. Philosophical Transactions. Series B: Biological Sciences, v. 236, p. 355-404, May 1952

* Not verified 
Mortimer, C. H., "Water Movements in Stratified Lakes, Deduced From Observations in Windermere and Model Experiments," International Association of ScientificHydrology. Brussels, 1951, v. 3, p. 335-349, 1952

Munk, W. H., "Internal Waves in the Gulf of California," Journal of Marine Research, v. 4, p. 81-91, 14 April 1941

Munk, W. and others, "Edge Waves on the Continental Shelf," Science, v. 123, p. 127-132, 27 January 1956

Munk, W. H. and others, "Spectra of Low-Frequency Ocean Waves," Scripps Institution of Oceanography. Bulletin, v. 7, p. 283-362, 1959

Murray, J., "On the Temperature of the Salt- and FreshWater Lochs of the West of Scotland at Different Depths and Seasons During the Years 1887 and 1888," Royal Society of Edinburgh. Proceedings, v. 18, p. 139-228, 1892

Nan'niti, T. and Ytiashi, M., "Fluctuations of Water Temperature off Turumi, Yokohama," Oceanographical Society of Japan. Journal, v. 13, p. 5-6, March 1957

Nansen, F., "The Oceanography of the North Polar Basin," in Nansen, F., ed., The Norwegian North Polar Expedition, 1893-1896: Scientific Results, v. 3, no. 9, Longmans Green, 1902

National Bureau of Standards Report 4415, An Experimental Study of Internal Solitary Waves, by G. H. Keulegan, 28 November 1955

National Bureau of Standards Report 7319, An Experimental Study of Internal Progressive Oscillatory Waves, by G. H. Keulegan and L. H. Carpenter, August 1961

Naval Ordnance Test Station, Internal Waves of Tidal Period Off Southern California, by K. O. Emery and H. J. Summers, 1960 (Unpublished Mimeographed Report) 
Navy Electronics Laboratory, Internal Tidal Waves and Their Stability Conditions, by A. Defant. (1961) (Translated From Archiv für Meteorologie, Geophysik, und Bioklimatologie, Ser. A, v. 1, p. 39-61, 1948-1949)

Navy Electronics Laboratory Report 709, Gravity Waves in the Lower Troposphere Over Southern California, by E. E. Gossard, 9 August 1956

Navy Electronics Laboratory Report 760, An Example of Sound-Ray Focusing by Internal Waves, by C. R. Sparger, 25 January 1957

Navy Electronics Laboratory Report 828, Slicks and Related Physical Properties of Near-Shore Waters (an Investigation of the Possible Effects of the Near-Shore Environment on Underwater Sound), by R. F. Dill and E. C. LaFond, CONFIDENTIAL, 29 April 1959

Navy Electronics Laboratory Report 937, Slicks and Temperature Structure in the Sea, by E. C. LaFond, 2 November 1959

Navy Electronics Laboratory Report 1124, A Mobile Temperature Sensing Array for the Ocean, by A. A. Hudimac and others, 27 July 1962

Navy Electronics Laboratory Report 1204, Internal Waves and Their Attached Slicks, by A. A. Hudimac and others, CONFIDENTIAL, 31 December 1963

*Navy Electronics Laboratory Technical Memorandum 549, Wave Making Resistance of a Body of Revolution Moving in a Two Layer Ocean, by A. A. Hudimac, 20 June 1962

Navy Electronics Laboratory, Waves in the Ocean, by F. G. Fisher and A. J. Keith, March 1949

*NEL technical memoranda are informal documents intended primarily for use within the Laboratory 
Neumann, G., "Stabilitätsschwingungen und die Innere Thermische Unruhe im Meer und in der Atmosphäre," Deutsche Hydrographische Zeitschrift, v. 2, p. 52-67, 1949

Neumann, G., "Stehende Zellulare Wellen im Meere," Naturwissenschaften, v. 33, p. 282-283, 1946

Office of Naval Research, London Branch Technical Report ONRL-78-61, Physical Marine Sciences in Kiel and Hamburg, by W. C. Thompson, p. 3-6, 29 August 1961

Pekeris, C. L., "Wave-Distribution in a Homogeneous Current (Abstract)," American Geophysical Union. Transactions, v. 19, p. 163-164, August 1938

Peluchon, G., "Travaux Océanographiques de L' 'ORIGNY' a Gibraltar; Campagne Internationale 15 Mai, 15 Juin, 1961," Cahiers Océanographiques, v. 14, p. 323-325, May 1962

Pettersson, H., "Bewegungen des Tiefenwassers an der Küste von Bohuslän im November 1915," Annalen der Hydrographie und Maritimen Meteorologie, v. 44, p. 270274,1916

*Pettersson, H., "Internal Movements in Coastal Waters and Meteorological Phenomena," Geografiska Annaler, v. 2, p. $33-66,1920$

Pettersson, H., "Internal Waves in Scandinavian Waters," International Geographic Congress. 12th Congress. Comptes-Rendus, v. 12, sec. 2b, p. 77, 1938

Pettersson, H., and Kullenberg, B., "Boundary Waves in the Kattegat," Gothenburg. Oceanografiska Institution. Meddelanden, no. 4, p. 1-23, 1933

* Not verified 
Pettersson, O., "Etudes sur les Mouvements Internes dan la Mer et dans 1'Atmosphere," Sweden. Svenska HydrografiskBiologiska Kommissionen. Skrifter, v. 7, 1922

Pettersson, O., "Gezeitenähnliche Bewegungen des Tiefenwassers," International Council for the Exploration of the Sea. Publications de Circonstance, no. 47, p. 1-21, 1909

Pettersson, O., "Innere Bewegungen in den Zwischenschichten des Meeres und der Atmosphäre," $\mathrm{K}$. Vetenskaps-Societeten i Upsala. Nova Acta Regiae Societatis Scientiarum Upsaliensi.s, ser. 4, v. 6, p. 1-43, 1923

Pettersson, O., "The Internal Parallactic Tide in the Transitional Area," International Council for the Exploration of the Sea, Rapports et Procès Verbaux des Reunions, v. 94, p. 25-30, 1935

Pettersson, O., "Interne Gezeiten-Wellen," International Council for the Exploration of the Sea, Rapports et Procès Verbaux des Reunions, v. 82, p. 1-26, I-VIII, 1933

Pettersson, O., "La Marée Interne," p. 294-309, James Johnstone Memorial Volume, Liverpool, 1934

Pettersson, O., "Tidvattnets Problem. I," Arkiv för Matematik, Astronomi och Fysik, v. 23A, no. 23, 10 October 1933

Pettersson, O., "Tidvattnets Problem, II: Erfurenheter och Experiment, en Studie: Geofysik," Arkiv för Matematik, Astronomi och Fysik, v. 24A, no. 17, 20 June 1934

Pettersson, O., "Tidvattnets Problem, III: Teori, en Studie i Geofysik," Arkiv för Matematik, Astronomi och Fysik, v. 24A, no. 16, 20 June 1934 
Pickard, G. L., "Oceanography of British Columbia Mainland Inlets, III: Internal Waves," No. 98 in Canada. Fisheries Research Board, Progress Reports of the Pacific Coast Stations, April 1954

Pritchard, D. W., Internal Waves and Their Effects on Results of Dynamic Computations (Seminar Paper),

17 November 1947

Proudman, J., Dynamical Oceanography, p. 333-401, Wiley, 1953

Queney, P., "The Problem of Air Flow Over Mountains: A Summary of Theoretical Studies," American Meteorological Society. Bulletin, v. 29, p. 16-26, 1948

Rand Corporation Paper P-2774, Turbulence, Diffusion, and Gravity Waves, by W. W. Kellogg, August 1963

Rattray, M., Jr., "Conditions of Coupling Between Long Surface and Internal Waves," p. 420-422 in International Oceanographic Congress, New York, 1959. Preprints of Abstracts of Papers to be Presented at Afternoon Sessions; Edited by Mary Sears, American Association for the Advancement of Science, 1959

Rattray, M., Jr., "GEK Observations of Inertial Oscillations (Abstract)," Journal of Geophysical Research, v. 67, p. 1654, April 1962

Rattray, M., Jr., "On the Coastal Generation of Internal Tides," Tellus; a Quarterly Journal of Geophysics, v. 12, p. $54-62$, February 1960

Rattray, M., Jr., "On the Offshore Distribution of Tide and Tidal Current," American Geophysical Union. Transactions, v. 38 , p. $675-680$, October 1957

Rattray, M., Jr., "Propagation and Dissipation of Long Internal Waves," American Geophysical Union. Transactions, v. 38 , p. $495-500$, August 1957 
Rayleigh, J. W. S., "Investigation of the Character of the Equilibrium of an Incompressible Heavy Liquid of Variable Density," London Mathematical Society. Proceedings, v. 14, p. 170-177, 1882-1883

Reid, J. L., Jr., "Observations of Inertial Rotation and Internal Waves," Deep-Sea Research, v. 9, p. 283-289, July/October 1962

Reid, J. L., Jr., "Observations on Internal Tides in October 1950," American Geophysical Union. Transactions, v. 37, p. $278-286$, June 1956

Revelle, R., "Sediments of the Gulf of California (Abstract)," Geological Society of America. Bulletin, v. 50, p. 1929, December 1939

Rossby, C. -G., "On the Mutual Adjustment of Pressure and Velocity Distributions in Certain Simple Current Systems," Journal of Marine Research, v. 1, p. 15-28, 1937-1938

Rossby, C. - G., "On the Mutual Adjustments of Pressure and Velocity Distributions in Certain Simple Current Systems, II," Journal of Marine Research, v. 1, p. 239$263,1937-1938$

Rudnick, P. and Cochrane, J. D., "Diurnal Fluctuations in Bathythermograms," Journal of Marine Research, v. 10, p. 257-262, 1951

Salsman, G. G., "A Note on Periodic Temperature Variations in the Gulf of Mexico Off Panama City, Florida," p. 442 in National Coastal and Shallow Water Research Conference, First. Proceedings, Tallahassee, 1961

Salsman, G. G. , "Temperature Variations in the Gulf of Mexico Off Panama City, Florida (Abstract)," Journal of Geophysical Research, v. 67, p. 3595, August 1962 
Sandström, J. W., "Dynamische Versuche mit Meerwasser," Annalen der Hydrographie und Maritimen Meteorologie, v. 36, p. $6-23,1908$

Sandström, W. J., "The Hydrodynamics of Canadian Atlantic Waters," Canadian Fisheries Expedition, 1914-1915, p. 231-243, Ottawa, 1918

Schmidt, M., "Stehende Schwingungen in der Grenzschicht Zweier Flüssigkeiten," Akademie der Wissenschaften, Vienna. Mathematisch - Naturwissenschaftliche Klasse, Sitzungsberichte, v. $177 \mathrm{IIa}$, p. 91-102, 1908

Schooley, A. H. and Stewart, R. W., "Experiments With a Self-Propelled Body Submerged in a Fluid With a Vertical Density Gradient," Journal of Fluid Mechanics, v. 15, p. 83-96, January 1963

Scorer, R. S., "Billow Clouds," Royal Meteorological Society. Quarterly Journal, v. 77, p. 235-240, 1951

Scorer, R. S., "The Dispersion of a Pressure Pulse in the Atmosphere," Royal Society of London. Proceedings. Series A: Mathematical and Physical Sciences, v. 201, p. 137-157, 7 March 1950

Scorer, R. S., "On the Stability of Stably Stratified Shearing Layers," Royal Meteorological Society. Quarterly Journal, v. 77, p. 76-84, 1951

Scorer, R. S., "Theory of Waves in the Lee of Mountains," Royal Meteorological Society. Quarterly Journal, v. 75, p. $41-56,1949$

Scott, O., "Die Wasserbewegungen im Gebiete der Gibraltar Strasse," Journal du Conseil (International Council for the Study of the Sea), v. 3, p. 139-175, September 1928

Seiwell, H. R., "An Analysis of Vertical Oscillations in the Southern North Atlantic," American Philosophical Society. Proceedings, v. 85, p. $136-158,1942$ 
Seiwell, H. R., "Daily Temperature Variations in the Western North Atlantic," Journal du Conseil (International Council for the Study of the Sea), v. 14, p. 357-369, December 1939

Seiwell, H. R., "The Effect of Short Period Variations of Temperature and Salinity on Calculations in Dynamic Oceanography," Papers in Physical Oceanography and Meteorology, v. 7, p. 1-32, November 1939

Seiwell, H. R., "Short Period Vertical Oscillations in the Western Basin of the North Atlantic," Papers in Physical Oceanography and Meteorology, v. 5, no. 2, May 1937

Seiwell, H. R., "Über die Ganz- und Halbtägige Mondkomponente der Internen Wellen im Westlichen Nordatlantischen Ozean," Annalen der Hydrographie und Maritimen Meteorologie, v. 66, p. 485-487, 1938

Sekera, Z., "Zur Wellenbewegung in Flüssigkeitsschichten mit Vertikal Veränderlicher Geschwindigkeit," Astrophysica Norvegica, v. 3, p. 1-69, 1938

Sekerzh-Zen'kovich, Ia. I., "Free Finite Oscillations of the Surface of Separation of Two Unlimited Heavy Liquids of Different Densities," Akademiia Nauk SSSR. Morskoi Gidrofizicheskii Institut. Trudy, v. 23, p. 3-43, 1961

Sekerzh-Zen'kovich, Ia. I., "On the Theory of' Free Finite Oscillations of a Surface Separating Two Unbounded. Heavy Liquids of Different Densities," Soviet Physics - Doklady, v. 6, p. 13-15, July 1961

Sekerzh-Zen'kovich, Ia. I., "Certain Questions of the Theory of the Propagation of Tidal Waves in a NonHomogeneous Fluid," Akademiia Nauk SSSR. Morskoi Gidrofizicheskii Institut, Trudy, v. 8, p. 3-32, August 1956

Sekerzh-Zen'kovich, Ia. I., "Propagation of Initial Disturbances on the Free Surface and at the Surface of the Division Between Two Layers of Liquids of Different Density," Akademiia Nauk SSSR. Morskoi Gidrofizicheskii Institut, Trudy, v. 17, p. 48-58, 1959 
Selitskaia, E. S., "The Problem of Internal Waves," Meteorologiia i Gidrologiia, Leningrad, no. 6, p. 35-39, June 1957

* Selitskaia, E. S., and Anuropova, L. V., "Zur Methodik der Gezeitenbedingten Temperaturschwankungen des Meerwassers," Leningrad. State Oceanographical Institute. Trudy, v. 67, p. 104-117, 1962

Sen-Gupta, B. K., "Large-Amplitude Periodic Lee Waves in Stratified Fluids, Part I, Non-Linear Solution," Royal Meteorological Society. Quarterly Journal, v. 88, $\overline{\text { p. 151- }}$ 155, April 1962

Sen-Gupta, B. K., "Large-Amplitude Periodic Lee Waves in Stratified Fluids, Part II, Linear Solution," Royal Meteorological Society. Quarterly Journal, v. 88, p. 426429, October 1962

* Shlyamin, B. A., "On the Internal Waves in the Black Sea," Azov-Black Sea NIRO. Transactions, Part 2, 1938

* Shliamin, B. A., "On the Internal Waves in the Southern Part of the Atlantic Ocean," Geograficheskoe Obshchestvo SSSR. Izvestiia, V. 85, 1957

Solberg, H., "Schwingungen und Wellenbewegungen in einer Atmosphäre mit Nach Oben Abnehmender Temperatur," Astrophysica Norvegica, v. 2, p. 123-172, 1937

Sretenskii, L. N., "The Cauchy-Poisson Method for the Discontinuity Surface Between Two Streams," Akademiia Nauk, S.S.S.R. Izvestiia. Seriia Geofizicheskaia, No. 6 , p. 505-513, November/December 1955

Sretenskii, L., "On the Wave Resistance of Ships in the Presence of Internal Waves," Akademiia Nauk, SSSR. Izvestiia. Otdelenie Tekhnicheskikh Nauk Mekhanika I Mashinostroenie, v. 1, p. 56-63, 1959

* Not verified 
Stevenson, R. E. and Grosline, D. S., "A Shoreward Movement of Cool Subsurface Water," American Geophysical Union. Transactions, v. 37, p. 553-557, October 1956

Stokes, G. G., "On the Theory of Oscillatory Waves," Cambridge Philosophical Society. Transactions, v. 8, p. 441-455, 1849

Stokes, G. G., "On the Theory of Oscillatory Waves," p. 197-229 in G. G. Stokes, Mathematical and Physical Papers, v. 1, Cambridge University Press, 1880

Stokes, G. G. , "Supplement to a Paper on the Theory of Oscillatory Waves," p. 314-326 in G. G. Stokes, Mathematical and Physical Papers, v. 1, Cambridge University Press, 1880

Stride, A. H. and Tucker, J. M., "Internal Waves and Waves of Sand," Nature, v. 188, p. 933, 10 December 1960

Subow, N., "Über Vertikale Schwankungen der Schichttiefen im Meerwasser," Annalen der Hydrographie und Maritimen Meteorologie, v. 57, p. 283-291, 1929

Summers, H. J. and Emery, K. O., "Internal Waves of Tidal Period Off Southern California," Journal of

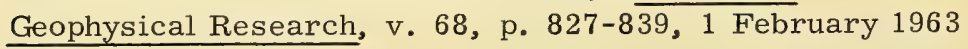

Summers, H. J. and others, Internal Waves of Tidal Period Off Southern California (3), (Unpublished Report), (1962)

Sverdrup, H. U. and others, The Oceans, p. 585-602, Prentice-Hall, 1942

Synge, J. L., "The Stability of Heterogeneous Liquids," Royal Society of Canada. Transactions, v. 27, p. 1-18, May 1933 
Takegami, T., "The Effect of a Local Wind Upon the Sea Surface and on the Internal Boundary Wave," Kyoto Imperial University. College of Science. Memoirs. Series A, v. 19, p. $109-130,1936$

Tareev, B. A., "Internal Waves in an Ocean Inhomogeneous With Respect to Density," Akademiia Nauk, S.S.S.R. Doklady: Series A, v. 149, p. 827-830, 1963

Taylor, G. I., "Effect of Variation in Density on the Stability of Superposed Streams of Fluid," Royal Society of London. Proceedings. Series A: Mathematical and Physical Sciences, v. 132, p. 499-523, 1931

Taylor, G. I., "Internal Waves and Turbulence in a Fluid of Variable Density," International Council for the Exploration of the Sea, Rapports et Procès Verbaux des Reunions, v. 76, p. $35-42,1931$

TEMPO Report Rm 63 TMP-11, Internal Waves and Related Surface Phenomena: A Bibliography, by D. W. Griesinger, CONFIDENTIAL, March 1963

Ter-Krikorov, A. M., "On Internal Waves in an Inhomogeneous Fluid," Applied Mathematics and Mechanics, v. 26, p. 1617-1631, 1962

Texas A \& M College. Oceanography Department Reference 62-5T, Opportunities for Environmental Research Off Panama City, Florida, by R. D. Gaul and others, 1 April 1962

Thomson, W., "On Stationary Waves in Flowing Water Part 1," Philosophical Magazine, Series 5, v. 22, p. 353357, October 1886

Thomson, W., "On Stationary Waves in Flowing Water Part 2," Philosophical Magazine, Series 5, v. 22, p. 445452, November 1886 
Thomson, W., "On Stationary Waves in Flowing Water Part 3," Philosophical Magazine, Series 5, v. 22, p. 517530, December 1886

Thorade, H., Probleme der Wasserwellen, Henri Grand, Hamburg, 1931

Tolstoy, I., "The Theory of Waves in Stratified Fluids Including the Effects of Gravity and Rotation," Reviews of Modern Physics, v. 35, p. 207-230, January 1963

Ufford, C. W., "Internal Waves in the Ocean," American Geophysical Union. Transactions, v. 28, p. 79-86, February 1947

Ufford, C. W., "Internal Waves Measured at Three Stations," American Geophysical Union. Transactions, v. 28, p. 8795, February 1947

Ufford, C. W., "The Theory of Internal Waves," American Geophysical Union. Transactions, v. 28, p. 96-101, February 1947

Underwater Sound Laboratory Technical Memorandum 105B-115-63, Three Russian Articles on Deep Sea Currents in the North Atlantic and Internal Waves of Tidal Period, by C. N. K. Mooers, 24 December 1963

University of California Division of War Research Report M289, Internal Waves, by C. W. Ufford, 19 March 1945

University of California Division of War Research Report M290, Internal Waves Off San Diego, California, by C. W. Ufford, 19 March 1945

University of California Division of War Research Report M406, Internal Waves Measured With Three Thermocouples, by C. W. Ufford, 12 April 1946 
University of California Division of War Research Report U3, A Laboratory Study of Surface and Internal Wave Motion, 23 November 1942

*Väisälä, V., "Über die Wirkung der Windschwangungen auf die Pilotbeobachtungen," Finska Vetenskaps-Societeten, Helsingfors. Commentationes Physico-Mathematicae. II, v. 19, p. 46,1925

Valdez, V., "Internal Waves on an Echo Sounder Record," Deep-Sea Research, v. 7, p. 148, 1960/1961

Vercelli, F., "Crociere per 1o Studio dei Fenomeni nello Stretto di Messina," Commissione Internazionale del Mediterraneo. Delegazione Italiana, Venezia, 1925-1926

Veronis, G. and Stommel, H., "The Action of Variable Wind Stresses on a Stratified Ocean," Journal of Marine Research, v. 15, p. 43-75, 1956

Voit, S. S., "Waves on the Surface of the Interface of Two Liquids, Appearing as the Result of the Changes of Position in the Periodic System of Pressure," Akademiia Nauk SSSR. Morskoi Gidrofizicheskii Institut, Trudy, v. 17, p. 33-40, 1959

Von Arx, W. S., An Introduction to Physical Oceanography, p. 76-77, Addison-Wesley, 1962

Warren, F. W. G., "Wave Resistance to Vertical Motion in a Stratified Fluid," Journal of Fluid Mechanics, v. 7, p. 209-229, February 1960

Washington University. Oceanography Department Reference 54-11, Propagation and Dissipation of Long Internal Waves, by M. Rattray, Jr., March 1954

Watson, E. R., "Movements of the Waters of Loch Ness as Indicated by Temperature Observations," Geographical Journal, v. 24, p. 430-437, October 1904 
Wedderburn, E. M., "Current Observations in Loch Garry," Royal Society of Edinburgh. Proceedings, v. 30, p. 312323, 1909-1910

Wedderburn, E. M., "Dr. O. Pettersson's Observations on Deep Water Oscillations," Royal Society of Edinburgh. Proceedings, v. 29, p. $602-606,1909$

Wedderburn, E. M., "Experimental Investigation of the Temperature-Changes Occurring in Fresh-Water Lochs," Royal Society of Edinburgh. Proceedings, v. 28, p. 2-20, 1907-1908

Wedderburn, E. M., "Temperature Observations in Loch Earn," Royal Society of Edinburgh. Transactions, v. 48, p. $629-695,1912$

Wedderburn, E. M., "Temperature Observations in Loch Garry," Royal Society of Edinburgh. Proceedings, v. 29, p. $98-135,1908-1909$

Wedderburn, E. M. and Watson, W., "Current Meter Observations in Loch Ness," Royal Society of Edinburgh. Proceedings, v. 29, p. 619-647, 1908-1909

Wedderburn, E. M. and Williams, A. M., "The Temperature Seiche," Royal Society of Edinburgh. Transactions, v. 47, p. $619-642,1911$

Wedderburn, E. M. and Young, A. W., "Temperature Observations in Loch Earn. Part II," Royal Society of Edinburgh. Transactions, v. 50, p. $74 \overline{1-767,1914-1915}$

Weigand, J. G. and Rattray, M., Jr., "Model Studies on the Coastal Generation of Internal Waves (Abstract)," Journal of Geophysical Research, v. 67, p. 1662, April 1962

Welander, P., "Response of the Ocean to a Time-Dependent Thermal Forcing (Abstract)," p. VI-29 in International Union of Geodesy and Geophysics General Assembly, 13th, 19-31 August 1963, Abstracts of Papers, Berkeley, 1963 
Williams, J., Oceanography, p. 176-177, Little, Brown, 1962

Witt, G., "Height, Structure and Displacements of Noctilucent Clouds," Tellus; a Quarterly Journal of

Geophysics, v. 14, p. 1-18, February 1962

Woods Hole Oceanographic Institution Reference 52-71, On the Reality of Internal Lunar Tidal Waves in the Ocean, by B. Haurwitz, September 1952

Woods Hole Oceanographic Institution Reference 53-69, Internal Tidal Waves in the Ocean, by B. Haurwitz, September 1953

Yasui, M., "Internal Waves in the Ocean," Oceanographical Magazine, v. 10, p. 227-234, December 1958

Yasui, M., "Internal Waves in the Open Ocean: An Example of Internal Waves Progressing Along the Oceanic Frontal Zone," Oceanographical Magazine, v. 12, p. 157-183, March 1961

Yasui, M., "Internal Waves in the Open Ocean: Internal Waves of Long Periods in the Ocean Weather Station

"'Tango," " Oceanographical Magazine, v. 12, p. 185-205, March 1961

Yih, C. S., "Effects of Density Variation on Fluid Flow," Journal of Geophysical Research, v. 64, p. 2219-2223, December 1959

Yih, C. S., "Gravity Waves in a Stratified Fluid," Journal of Fluid Mechanics, v. 8, p. 481-508, August 1960

Yih, C. S., "On Stratified Flows in a Gravitational Field," Tellus; a Quarterly Journal of Geophysics, v. 9, p. 220228, May 1957 
Zeilon, N., "Experiments on Boundary Tides-A Preliminary Report," Göteborgs K. Vetenskaps - och Vitterhets Samhälle, Gothenburg. Handlingar. Ny Tidsföljd. -SB: Mathematiska och Naturvetenskapliga Skrifter, Ser. 5, v. 3, p. 1-13, 1934

*Zeilon, N., "On the Influence of Diffusion Upon the Propagation of Boundary Waves," K. Vetenskaps-Societeten i Upsala. Nova Acta Regiae Societatis Scientiarum, v. 4, p. $1-16,1915$

Zeilon, N., "On the Seiches of the Gullmar Fjord," Sweden. Svenska Hydrografisk-Biologiska Kommissionen. Skrifter, v. 5, p. 1-18, 1913

Zeilon, N., "On Tidal Boundary-Waves and Related Hydrodynamical Problems," Svenska Vetenskapsakademien, Stockholm. Handlingar, v. 47, p. 1-46, 1912

*Not verified 
UNCIASSIFIED

Security Classification

\section{DOCUMENT CONTROL DATA - R\&D}

(Security classification of title, body of abstract and indexing annotation must be entered when the overall report is classified) 1. ORIGINATIN G ACTIVITY (Comorate author)

Navy Electronics Laboratory,

San Diego, Calif. 92152 2 a. REPORT SECURITY CLASSIFICATION UNCLASSIFIED

2b. GROUP None

3. REPORT TITLE

INTERNAL WAVES IN THE SEA

4. DESCRIPTIVE NOTES (TyPe of repart and inclusive detes)

Research and Development, June 1963 to June 1964

5. AUTHOR(S) (Last name, first name, initial)

Lee, O. S.

\begin{tabular}{|c|c|c|}
\hline $\begin{array}{l}\text { 6. REPORT DATE } \\
26 \text { July } 1965\end{array}$ & $\begin{array}{l}\text { 7a. TOTAL NO. OF PAGES } \\
58\end{array}$ & $\begin{array}{l}\text { 7b. NO. OF REFS } \\
355\end{array}$ \\
\hline $\begin{array}{l}\text { 8a. CONTRACT OR GRANT NO. } \\
\begin{array}{cl}\text { SR } 0040301, & \text { Task } 0580 \\
\text { B. PROJECT NO. } & \text { (NEL L40451) }\end{array}\end{array}$ & \multicolumn{2}{|c|}{$\begin{array}{l}\text { 9. ORIGINATOR'S REPORT NUMBER(S) } \\
1302\end{array}$} \\
\hline & \multicolumn{2}{|c|}{$\begin{array}{l}\text { 9b. OPHER REPORT NO(S) (Any othor numbers that may bo assignod } \\
\text { (his report) }\end{array}$} \\
\hline \multicolumn{3}{|c|}{$\begin{array}{l}\text { 10. AVAILABILITY/LIMITATION NOTICES Qualified requesters may obtain copies of this } \\
\text { report from DDC. Also available from Clearinghouse for Federal } \\
\text { Scientific and Technical Information, Springfield, Virginia } 22151 \text {. }\end{array}$} \\
\hline 1. SUPPL EMENTARY NOTES & $\begin{array}{l}\text { 12. SPONSORING MILITARYA } \\
\text { Bureau of Ships, } \\
\text { Washington, D. C }\end{array}$ & $\begin{array}{l}\text { vitr } \\
\text { partment of the Navy, } \\
20360\end{array}$ \\
\hline
\end{tabular}

13. ABSTRACT

This report presents a bibliography of over 300 listings and summarizes important published results of investigation. Internal waves are shown to exist as a rule, rather than as an exception. They transport energy in channels similar to sound channels. Effects on sonar are greatest in these channels. 
UNCLASSIFIED

Security Classification

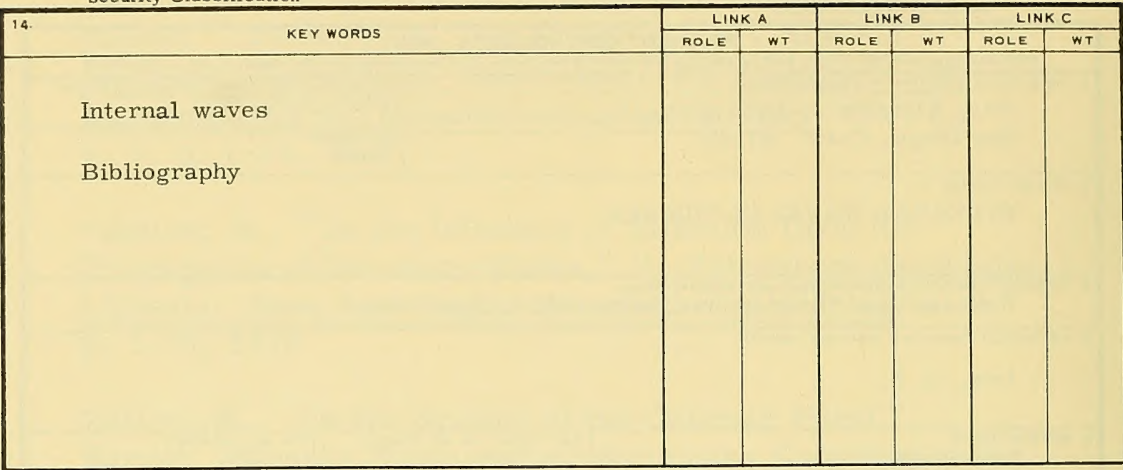

\section{INSTRUCTIONS}

1. ORIGINATING ACTIVITY: Enter the name and address of the contractor, subcontractor, grantee, Department of De fense activity or other organization (comorate author) issuing the report.

2a. REPORT SECURTY CLASSIFICATION: Enter the overall security classification of the report. Indicate whether "Restricted Data" is included. Marking is to be in accordance with appropriate security regulations.

2b. GROUP: Automatic downgrading is specified in DoD Directive 5200.10 and Armed Forces Industrial Manual. Enter the group number. Also, when applicable, show that optional markings have been us ed for Group 3 and Group 4 as authorized.

3. REPORT TITLE: Enter the complete report title in all capital letters. Titles in all cases should be unclassified. If a meaningful title cannot be selected without classification, show title classification in all capitals in parenthesis immediately following the title.

4. DESCRIPTIVE NOTES: If appropriate, enter the type of report, e.g. interim, progress, summary, annual, or final.

Give the inclusive dates when a specific reporting period is covered.

5. AUTHOR(S): Enter the name(s) of author(s) as shown on or in the report. Enter last name, first name, middle initial. If military, show rank an.t branch of service. The name of the principal author is an ahsolute minimum requirement.

6. REPORT DATE: Enter the date of the report as day, month year' or month, year. If more than one date appears on the report, use date of publication.

7a. TOTAL NUMBER OF PAGES: The total page count should follow normal pagination procedures, i. e., enter the number of pages containing information.

7b. NUMBER OF REFERENCES. Enter the total number of references cited in the report.

8a. CONTRACT OR GRANT NUMBER: If appropriate, enter the applicable number of the contract or grant under which

the report was written

$8 b, 8 c, \& 8 d$. PROJECT NUMBER: Enter the appropriate military department identification, such as project number, subproject number, system numbers, task number, etc.

9a. ORIGINATOR'S REPORT NUMBER(S): Enter the official report number by which the document will be identified and controlled by the originating activity. This number must be unique to this report.

9b. OTHER REPORT NUMBER(S): If the report has been assigned any other report numbers (either by the originator or by the sponsor), also enter this number(s)

10. AVAILABILITY/LIMITATION NOTICES: Enter any limitations on further dissemination of the report, other than those imposed by security classification, using standard statements such as:

(1) "Qualified requesters may obtain copies of this report from DDC."

(2) "Foreign announcement and dissemination of this report by DDC is not authorized."

(3) "U. S. Government agencies may obtain copies of this report directly from DDC. Other qualified DDC users shall request through

(4) "U. S. military agencies may obtain copies of this report directly from DDC. Other qualified users shall request through

(5) "All distribution of this report is controlled Qualified DDC users shall request through

If the report has been furnished to the Office of Technical Services, Department of Commerce, for sale to the public, indicate this fact and enter the price, if known.

11. SUPPLEMENTARY NOTES: Use for additional explanatory notes.

12. SPONSORING MILITARY ACTIVITY: Enter the name of the departmental project office or Iaboratory sponsoring (paying for) the research and development. Include address.

13. ABSTRACT: Enter an abstract giving a brief and factual summary of the document indicative of the report, even though it may also appear elsewhere in the body of the technical report. If additional space is required, a continuation sheet shall port. If addi
be attached.

It is highly desirable that the abstract of classified reports be unclassified. Each paragraph of the abstract shall end with an indication of the military security classification of the information in the paragraph, represented as $(T S)$. (S). (C), or (U).

There is no limitation on the length of the abstract. How ever, the suggested length is from 150 to 225 words.

14. KEY WORDS: Key words are technically meaningful terms or short phrases that characterize a report and may be used as index entries for cataloging the report. Key words must be selected so that no security classification is required. Identifiers, such as equipment model designation, trade name, military project code name, geographic location, may be used as key words but will be followed by an indication of technical context. The assignment of links, roles, and weights is optional. 


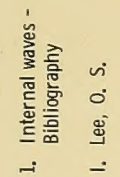

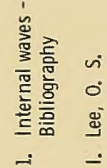

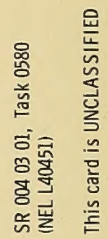

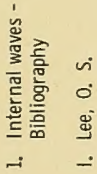

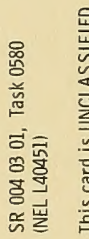

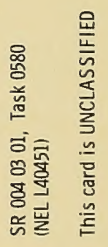

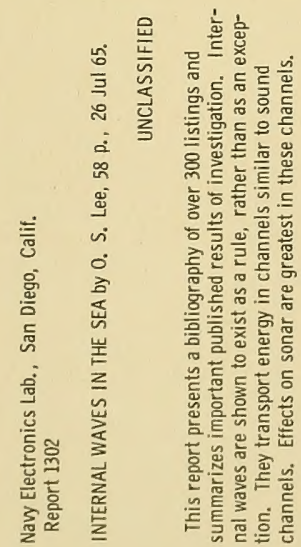

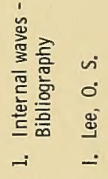

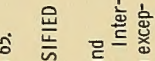

इ

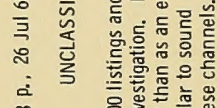

象

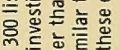

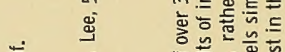

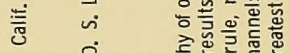

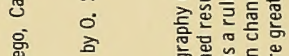

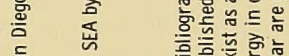

㟧 崫 言

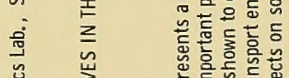

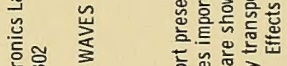

总嵒专

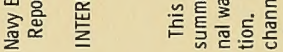

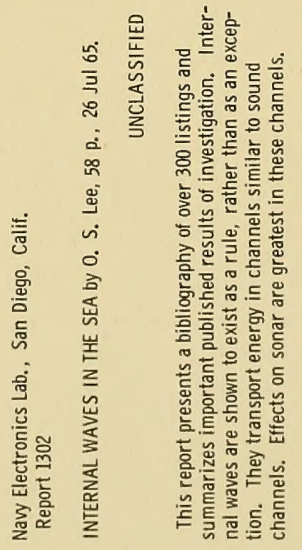


CHIEF, BUREAU OF SHIPS

CODE 1620

CODE $210 \mathrm{~L}$ (2)

CODE 320

CHIEF, BUREAU OF NAVAL WEAPONS

OL I -3

$\mathrm{DLI}=3 \mathrm{I}$

FASS

RU -222

RUDC - 2

CHIEF, BUREAU OF YARDS AND DOCKS

CHIEF OF NAVAL PERSONNEL.

PERS $11 B$

CHIEF OF NAVAL OPERATIONS

OP $-07 T$

$O P \rightarrow 71$

$\mathrm{OP}-03 \mathrm{EG}$

OP-09B5

CHIEF OF NAVAL RESEARCH

CODE 416

CODE 466

CODE 468

COMMANDER IN CHIEF US PACIFIC FLEET

COMMANDER IN CHIEF US ATLANTIC FLEET

COMMANDER OPERATIONAL TEST AND

EVALUATION FORCE

DEPUTY COMMANDER OPERATIONAL TEST -

EVALUATION FORCE, PACIFIC

COMMANDER CRUISER-DESTROYER FORCE,

US ATLANTIC FLEET

US ATLANTIC FLEET

COMMANDER TRAINING COMMAND

US PACIFIC FLEET

OCEANOGRAPHIC SYSTEM PACIFIC (2)

COMMANDER SUBMARINE DEVELOPMENT GROUP TWO

FLEET AIR WINGS, ATLANTIC FLEET SCIENTIFIC ADVISORY TEAM

US NAVAL AIR DEVELOPMENT CENTER NADC LIBRARY

US NAVAL MISSILE CENTER

TECH. LIBRARY, CODE NO 3022

PACIFIC MISSILE RANGE /CODE $3250 /$

US NAVAL ORDNANCE LABORATORY LIBRARY

US NAVAL ORDNANCE TEST STATION PASADENA ANNEX LIBRARY

CHINA LAKE

US NAYAL WEAPONS LABORATORY $\mathrm{KXL}$

PUGET SOUND NAVAL SHIPYARD

USN RADIOLOGICAL DEFENSE LABORATORY

DAVI TAYLR MODEL

APPLIED MATHEMATICS LABORATORY APPLIED MATH

US 'LIBRARY'

US NAVY MINE DEFENSE LABORATORY CODE. $365 \mathrm{H}$. ASW DIVISION

USN UNDERWATER SOUND LABORATORY USN UNDERWATER

LIBRARY (3)

ATLANTIC FLEET ASW TACTICAL SCHOOL

USN MARINE ENGINEERING LABORATORY

US NAVAL CIVIL ENGINEERING LAB. LS4

US NAVAL RESEARCH LABORATORY CODE 2027

US NAVAL ORDNANCE LABORATORY CORONA

USN UNDERWATER SOUND REFERENCE LAB. BEACH JUMPER UNIT TWO

US FLEET ASW SCHOOL

USN UNDERWATER ORDNANCE STATION

OFFICE OF NAVAL RESEARCH

PASADENA

USN WEATHER RESEARCH FACILITY

US NAVAL OCEANOGRAPHIC OFFICE

US NAVAL POSTGRADUATE SCHOOL

LIBRARY (2)

LIBRARY (2)

DEPT OF ENVIRONMENTAL

LONDON

BOSTON

CHICAGO

SAN FRANCISCO

FLEFT NUMERICAL WEATHER FACILITY

US NAVAL APPLIED SCIENCE LABORATORY CODE 9832
US NAVAL ACADEMY

ASSISTANT SECRETARY OF THE NAVY R-D

ONR SCIENTIFIC LIAISON OFFICER

WOODS HOLE OCEANOGRAPHIC INSTITUTION INSTITUTE OF NAVAL STUDIES

LIBRARY

AIR DEVELOPMENT SQUADRON ONE IVX-1

DEFENSE DOCUMENTATION CENTER (20)

DOD RESEARCH AND ENGINEERING

TECHNICAL LIBRARY

NATIONAL OCEANOGRAPHIC DATA CENTER (2)

NASA

LANGLEY RESEARCH CENTER (3)

US COAST GUARD

OCEANOGRAPHY - METEOROLOGY BRANCH

ARCTIC RESEARCH LABORATORY

WOODS HOLE OCEANOGRAPHIC INSTITUTION

US COAST AND GEODETIC SURVEY

MARINE DATA DIVISION /ATTN-2

US WEATHER BUREAU

US GEOLOGICAL SURVEY LIBRARY

DENVER SECTION

US BUREAU OF COMMERCIAL FISHERIES

LA JOLLA DR. AHLSTROM

WASHINGTON $25, D$.

WOODS HOLE. MASSACHUSETTS

HONOLULU-JOHN C MARR

LA JOLLA, CALIFORNI

HONOLULU, HAWAII

POINT LOMA STA-J. H. JOHNSON

ABERDEEN PROVING GROUND. MARYLAND

REDSTONE SCIENTIFIC INFORMATION

CENTER

BEACH EROSION BOARD

CORPS OF ENGINEERS, US ARMY

DEPUTY CHIEF OF STAFF, US AIR FORCE AFRST-SC

STRATEGIC AIR COMMAND

HQ AIR WEATHER SERVIC

UNIVERSITY OF MIAMI

THE MARINE LAB. LIBRARY (3)

COLUMBIA UNIVERSITY

HUDSON LABORATORIES

LAMONT GEOLOGICAL OBSERVATORY

DARTMOUTH COLLEGE

THAYER SCHOOL OF ENGINEERING

RAD IOPHYSICS LABORATORY

RUTGERS UNIVERSITY

CORNELL UNIVERSITY

OREGON STATE UNIVERSITY

DEPARTMENT OF OCEANOGRAPHY

UNIVERSITY OF SOUTHERN CALIFORNIA

ALLAN HANCOCK FOUNDATION

UNIVERSITY OF WASHINGTON

DEPARTMENT OF OCEANOGRAPHY

ISHERIES-OCEANOGRAPHY LIBRARY

NEW YORK UNIVERSITY

DEPT OF METEOROLOGY - OCEANOGRAPHY

UNIVERSITY OF MICHIGAN

DR. JOHN C. AYERS (2)

NIVERSITY OF ALASKA

GEOPHYSICAL INSTITUTE

UNIVERSITY OF RHODE ISLAND

NARRAGANSETT MARINE LABORATORY

YALE UNIVERSITY

BINGHAM OCEANOGRAPHIC LABORATORY

FLORIDA STATE UNIVERSITY

OCEANOGRAPHIC INSTITUTE

INIVERSITY OF HAWAI

HAWAII INSTITUTE OF GEOPHYSICS

ELECTRICAL ENGINEERING DEPT

A-M COLLEGE OF TEXAS

DEPARTMENT OF OCEANOGRAPHY

THE UNIVERSITY OF TEXAS

DEFENSE RESEARCH LABORATORY

HARVARD UNIVERSITY

SCRIPPS INSTITUTION OF OCEANOGRAPHY MARINE PHYSICAL LAB

UNIVERSITY OF CALIFORNIA

ENGINEERING DEPARTMENT

UNIVERSITY OF CALIFORNIA, SAN DIEGO SIO

THE JOHNS HOPKINS UNIVERSITY

APPLIED PHYSICS LABORATORY

INSTITUTE FOR DEFENSE ANALYSIS

FLORIDA ATLANTIC UNIVERSITY 